San Jose State University

SJSU ScholarWorks

Master's Theses

Master's Theses and Graduate Research

2009

\title{
The role of dinB in UV survival and UV-induced mutagenesis in Escherichia coli
}

Mei-Chong Wendy Lee

San Jose State University

Follow this and additional works at: https://scholarworks.sjsu.edu/etd_theses

\section{Recommended Citation}

Lee, Mei-Chong Wendy, "The role of dinB in UV survival and UV-induced mutagenesis in Escherichia coli" (2009). Master's Theses. 3686.

DOI: https://doi.org/10.31979/etd.us32-w67v

https://scholarworks.sjsu.edu/etd_theses/3686

This Thesis is brought to you for free and open access by the Master's Theses and Graduate Research at SJSU ScholarWorks. It has been accepted for inclusion in Master's Theses by an authorized administrator of SJSU ScholarWorks. For more information, please contact scholarworks@sjsu.edu. 


\title{
THE ROLE OF $\operatorname{din} B$ IN UV SURVIVAL AND UV-INDUCED MUTAGENESIS IN ESCHERICHIA COLI
}

\author{
A Thesis \\ Presented to \\ The Faculty of the Department of Biological Sciences \\ San José State University
}

\author{
In Partial Fulfillment \\ of the Requirements for the Degree \\ Master of Science
}

by

Mei-Chong Wendy Lee

May 2009 
UMI Number: 1470985

\section{INFORMATION TO USERS}

The quality of this reproduction is dependent upon the quality of the copy submitted. Broken or indistinct print, colored or poor quality illustrations and photographs, print bleed-through, substandard margins, and improper alignment can adversely affect reproduction.

In the unlikely event that the author did not send a complete manuscript and there are missing pages, these will be noted. Also, if unauthorized copyright material had to be removed, a note will indicate the deletion.

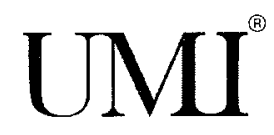

UMI Microform 1470985

Copyright 2009 by ProQuest LLC

All rights reserved. This microform edition is protected against unauthorized copying under Title 17, United States Code.

ProQuest LLC

789 East Eisenhower Parkway

P.O. Box 1346

Ann Arbor, MI 48106-1346 
(C) 2009

Mei-Chong Wendy Lee

ALL RIGHTS RESERVED 


\title{
SAN JOSÉ STATE UNIVERSITY
}

The Undersigned Thesis Committee Approves the Thesis Titled

\section{THE ROLE OF $\operatorname{din} B$ IN UV SURVIVAL AND UV-INDUCED MUTAGENESIS IN ESCHERICHIA COLI}

\author{
by \\ Mei-Chong Wendy Lee
}

\section{APPROVED FOR THE DEPARTMENT OF BIOLOGICAL SCIENCES}
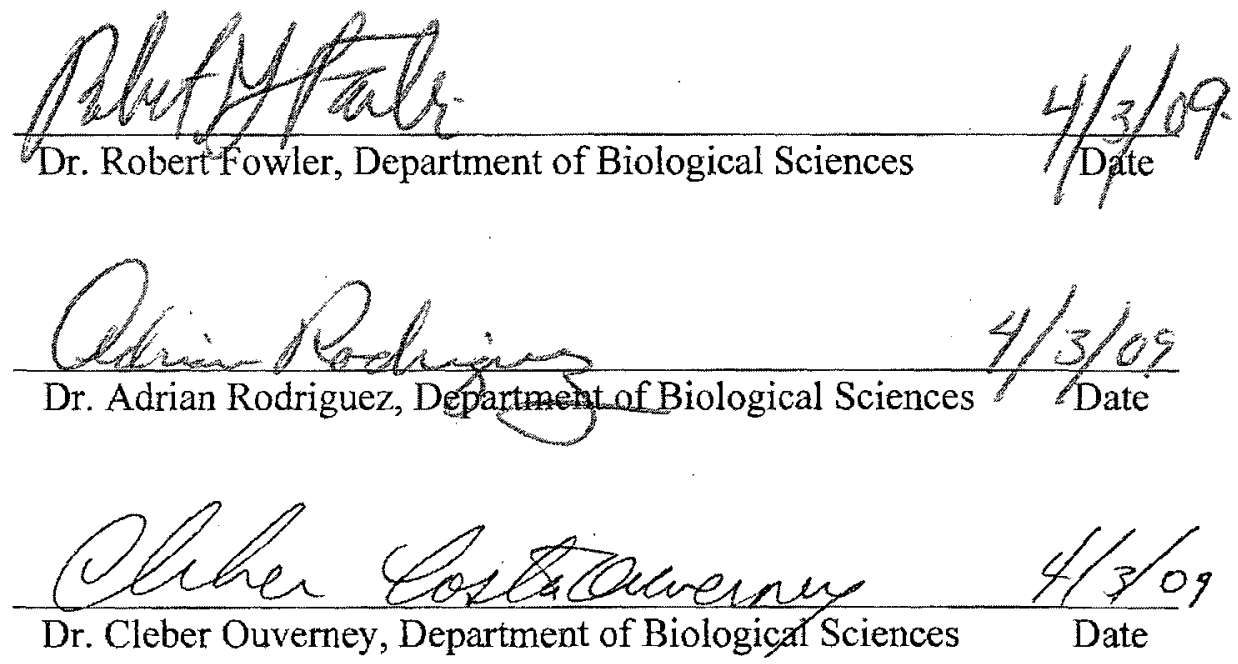

APPROVED FOR THE UNIVERSITY

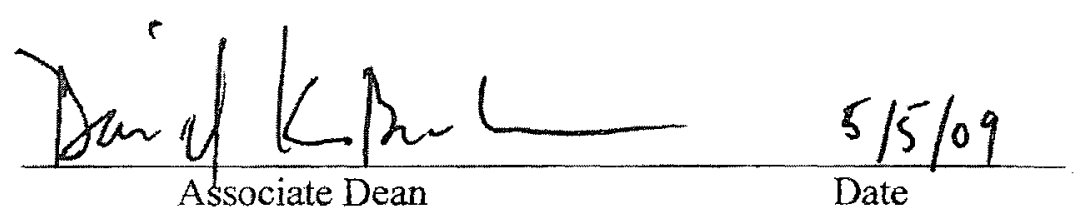




\title{
ABSTRACT \\ THE ROLE OF $\operatorname{din} B$ IN UV SURVIVAL AND UV-INDUCED MUTAGENESIS IN ESCHERICHIA COLI
}

\author{
by Mei-Chong Wendy Lee
}

This study addresses the possible function of the Escherichia coli $\operatorname{din} B$ gene in spontaneous and UV-induced mutagenesis and DNA repair triggered by UV-induced damage. The $\operatorname{trp} A$ reversion system was used to study spontaneous and UV mutagenesis. This system involved strains carrying specific trpA alleles. Revertants were selected that had regained the wild-type phenotype of synthesizing tryptophan. The trpA spontaneous and UV-induced revertants were sequenced, and the molecular nature of the original mutations and of the revertants was determined. The $\operatorname{din} B$ allele, the $u m u C$ allele, and the combination of both were examined for their effect on spontaneous and UV mutagenesis. The results show that $\operatorname{din} B$ was not significantly involved in spontaneous and UV mutagenesis. The involvement of DinB and UmuC in UV survival was studied through a 20-hour period of growth. It appears that DinB and UmuC were essential for UV repair and cell survival in the log phase of growth. The effect of $\operatorname{din} B$ on UV survival and UV mutagenesis was dependent upon an active $u m u C$ allele. In contrast to the $\operatorname{din} B$ strain with a polar deletion mutation that showed a higher level of UV sensitivity, a $\operatorname{din} B$ strain with a missense nonpolar mutation showed no UV sensitivity. This suggests that either a downstream gene from $\operatorname{din} B$ is actually responsible for protection from UV damage or the function of DinB is not dependent upon its polymerase activity. 


\section{ACKNOWLEDGEMENTS}

I would like to thank Dr. Robert Fowler for his support and guidance throughout the process of my research and the preparation of this thesis. I am extremely grateful to Magdalena Franco who has worked with me on my research and for always being supportive. I want to thank Mouna Jabri for performing most of the transductions and for preparing the culture media. A special gratitude must also be extended to Nancy Fong, Ricardo Leitão, Vicki Tran, and Paula Matheus for proofreading this thesis. Great appreciation is also due to Dr. Adrian Rodriguez and Dr. Cleber Ouverney for reviewing this thesis. The completion of this thesis would not have been possible without the support from my parents, family, and friends. Last but not least, I would like to thank my loving husband, Dominic Abucejo, for his unconditional love and encouragements. 


\section{TABLE OF CONTENTS}

PAGE

LIST OF TABLES ….................................................... viii

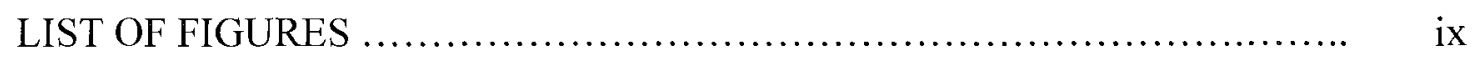

1. INTRODUCTION ...................................................... 1

2. LITERATURE REVIEW .............................................. 2

2.1 UV damage and nucleotide excision repair ......................... 2

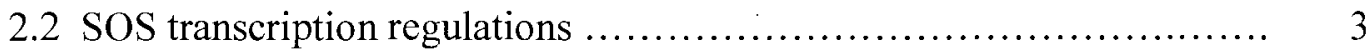

2.3 Unique features of Y-family polymerases ......................... 4

2.4 Role of DinB in mutagenesis .................................... 5

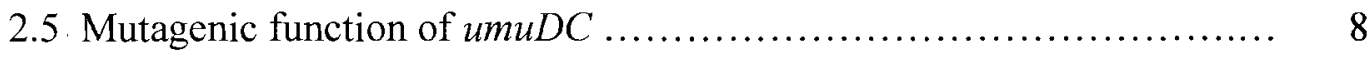

2.6 The roles of Pol II in replication restart and translesion synthesis ....... 11

2.7 Modulation of function by protein-protein interactions ................. 12

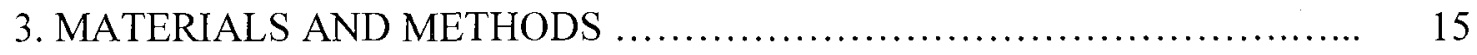

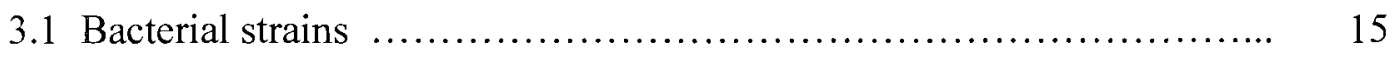

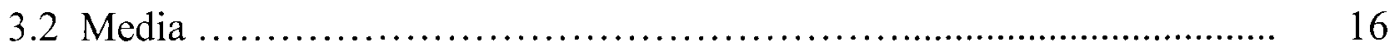

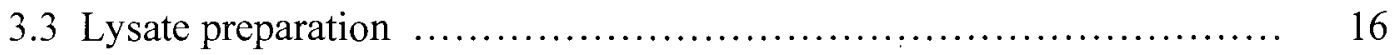

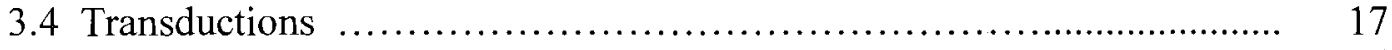

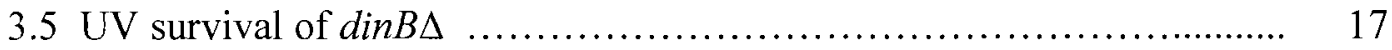

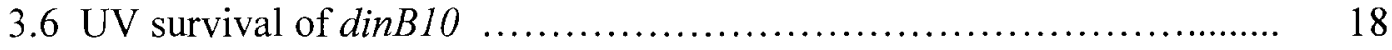

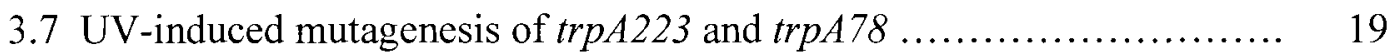

3.8 Spontaneous mutagenesis and reversion frequencies $\ldots \ldots \ldots \ldots \ldots \ldots \ldots . . . \ldots$

3.9 PCR amplification of the $t r p^{+}$gene ................................. 20

4. RESULTS ........................................................... 22

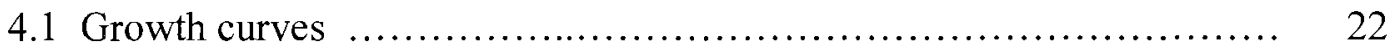


4.2 Cell survival in UV-exposed $\operatorname{din} B \Delta$ and $u m u C$ strains in a 20 -hour growth period

4.3 The effect of $\operatorname{din} B 10$ on UV survival ............................... 22

4.4 UV-induced mutagenesis and spontaneous mutagenesis ............... 23

4.5 Characterization and distribution of spontaneous $\operatorname{Trp}^{+}$revertants ...... 23

5. DISCUSSION .......................................................... 31

5.1 The role of DinB in UV damage repair ............................ 31

5.2 The effect of polar $\operatorname{din} B \Delta$ and nonpolar $\operatorname{din} B 10$ on UV damage repair ... 33

5.3 The role of $\operatorname{din} B$ in $\mathrm{UV}$-induced mutagenesis and spontaneous mutagenesis ....................................................... 35

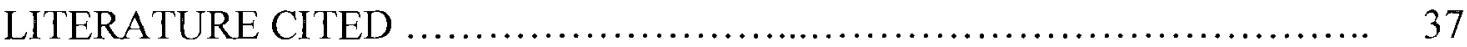




\section{LIST OF TABLES}

PAGE

Table 1. Escherichia coli strains used in this study 15

Table 2. UV-induced $\operatorname{Trp}^{+}$reversion frequencies of $\operatorname{trp} A$ base-pair substitution alleles in wild-type and $\operatorname{din} B \triangle$ strains

Table 3. Spontaneous $\operatorname{Trp}^{+}$reversion frequencies for base-pair substitution and frameshift $\operatorname{trp} A$ alleles in wild-type, $\operatorname{din} B \Delta, u m u C$, and $\operatorname{din} B \triangle u m u C$ backgrounds

Table 4. Spontaneous $\operatorname{Trp}^{+}$reversion frequencies of $\operatorname{trp} A 223$ in wild-type and $\operatorname{din} B \Delta$ strains 


\section{LIST OF FIGURES}

PAGE

Figure 1. 20-hour growth curves of $\operatorname{din} B^{+} u m u C^{+}, \operatorname{din} B \Delta u m u C^{+}$,

$\operatorname{din} B^{+} u m u C$, and $\operatorname{din} B \Delta u m u C$

Figure 2. Effect of the $\operatorname{din} B \Delta$ and $u m u C$ mutations on the UV radiation survival of E.coli trpA223 in a 20 -hour growth period 26

Figure 3. The comparison of the UV survival of the polar and nonpolar $\operatorname{din} B$ strains with wild-type strains 


\section{INTRODUCTION}

Ultraviolet (UV) light can damage DNA by causing the formation of pyrimidine (6 -4) pyrimidone photoproducts and cyclobutane dimer. Photoreactivation and nucleotide excision repair (NER) are the two common mechanisms for repairing UV-induced lesions in Escherichia coli. However, if the lesion is not repaired, the replicative DNA

polymerase (Pol III) often stalls at the replication fork when it encounters a damaged DNA template base. The SOS regulatory network will then be activated. One repair mechanism in the SOS response involves translesion DNA synthesis where novel DNA polymerases catalyze DNA synthesis past DNA lesions. This is also known as a DNAtolerance mechanism because the damage is not removed. This is a way to avoid cell death as a consequence of unrepaired or unrepairable damage to genomes. Approximately 40 genes are involved in the SOS regulatory network. There are three SOS genes encoding DNA polymerases: Pol II, Pol IV (DinB), and Pol V (UmuC). Pol II is a highfidelity polymerase that belongs to the B-family of polymerases. DinB and UmuC are error-prone polymerases that are members of the Y-family polymerases. Little is known about the role of DinB in UV mutagenesis and UV survival. UmuC and Pol II were found to be involved in UV repair in previous studies. In this study, the roles of the $\operatorname{din} B$ gene in UV survival and UV and spontaneous mutagenesis, and its relationship with $u m u C$ are investigated. The effect upon UV survival of the polar deletion mutation in $\operatorname{din} B$ is compared with that of a nonpolar $\operatorname{din} B$ missense mutation. 


\section{LITERATURE REVIEW}

\subsection{UV damage and nucleotide excision repair}

UV light can cause two adjacent pyrimidine molecules to dimerize. A process called photoreactivation can revert the dimerization. Photoreactivation occurs when a photon activates an enzyme, photolyase, encoded by the phr gene and splits the pyrimidine dimer apart (Russell, 2003). Another repair mechanism, nucleotide excision repair (NER), can correct the pyrimidine dimer without the need of light. It can also repair DNA that has serious damage-induced helix distortion. There are four proteins that are involved in NER: UvrA, UvrB, UvrC, and UvrD, encoded by $u v r A, u v r B, u v r C$, and $u v r D$, respectively (Russell, 2003). First, two UvrA proteins and one UvrB protein form a complex and slide along the DNA. When the complex recognizes a pyrimidine dimer, the UvrA proteins dissociate. UvrC then binds to UvrB at the site of the lesion. UvrC makes a cut four or five nucleotides to the $3^{\prime}$ side of the lesion and a cut about eight nucleotides to the $5^{\prime}$ side of the lesion. After UvrB is released, UvrD binds to the $5^{\prime}$ cut, unwinds the region between the cuts, and releases the short single-stranded DNA. DNA polymerase I fills in the gap in the $5^{\prime} \rightarrow 3^{\prime}$ direction, and DNA ligase seals the gap. If the UV-induced DNA damage is too severe, some of the lesions can remain unrepaired. The replicative polyermase (Pol III) will arrest when it encounters the UV-induced DNA lesion, and the SOS response will be triggered. 


\subsection{SOS transcription regulations}

SOS-regulated gene expression is under very stringent control. The gene products of the lexA gene and the recA gene regulate the expression of the SOS-regulated genes. In E. coli cells that have not been exposed to DNA damage, the product of the lexA gene acts as a repressor of more than 40 genes by binding as a homodimer to similar operator sequences to each operon. The operator sequences that bind to the LexA protein are commonly referred to as SOS boxes (Friedberg et al., 2006). Many of these SOS genes, including $\operatorname{rec} A$ and $\operatorname{lex} A$, are expressed at significant levels even in the repressed state. In particular, RecA protein expresses at approximately 7,200 molecules per cell in uninduced cells (Sassanfar and Roberts, 1991). When replication is stalled by DNA damage, an intracellular signal for SOS induction is initiated. The recA gene product binds to the single-stranded DNA produced at the replication fork, forming a nucleoprotein filament in the presence of nucleoside triphosphates (Craig and Roberts, 1980). LexA molecules then diffuse to the deep grooves in the RecA-ssDNA filaments. The interaction of LexA with the RecA nucleoprotein filament results in proteolytic cleavage of LexA at a specific Ala-Gly bond near the middle of the protein (Friedberg et al., 2006). Cleavage of LexA protein inactivates LexA as a repressor. The cleaved LexA proteins are targeted for destruction. As LexA cleavage proceeds after an SOS-inducing treatment, the pool of LexA proteins begins to decrease. A number of SOS genes, including $r e c A$, $\operatorname{din} B$, and $u m u D C$, are expressed at increased levels, and SOS-induced DNA repair and tolerance begins. As the cells begin to recover from the SOS-inducing treatment, the region of ssDNA disappears as a consequence of various DNA repair and 
tolerance processes (Friedberg et al., 2006). The amount of RecA protein present in RecA-ssDNA filaments declines. Continued synthesis of LexA protein then leads to an increase in the LexA pool, which leads to a repression of the SOS genes.

\subsection{Unique features of Y-family polymerases}

As mentioned earlier, DinB and UmuC are error-prone Y-family polymerases. Yfamily polymerases share no clear sequence homology with replicative polymerases, but their structures reveal a similar right-hand fold consisting of a thumb, palm, and fingers domain (Ling et al., 2001). These polymerases have an additional little finger domain that seems to play an important part in substrate specificity and processivity (Boudsocq $e t$ al., 2004). It has been shown that the little finger domain interacts with the processivity clamp known as the $\beta$ clamp. In the presence of the $\beta$ clamp, Y-family polymerases exhibit 300-fold enhanced processivity (Wagner et al., 2000). Unlike the tight grip seen in the active sites of replicative DNA polymerases, Y-family polymerases have an open active site that is relatively solvent-accessible (Johnson et al., 2003). It is believed that the open active site is essential for accommodating the bulky adducts on the damaged DNA template (Ling et al., 2001). An $\alpha$-helix responsible for a geometric check to ensure the fidelity of the incipient base pair in the replicative DNA polymerases is absent in Y-family polymerases (Jarosz et al., 2007). Additionally, Y-family polymerases lack

$3^{\prime}$ to $5^{\prime}$ exonuclease (proofreading) activity. Thus, most translesion syntheses are inherently error prone. Y-family polymerases typically exhibit 10-1000-fold lower fidelity than replicative DNA polymerases when replicating undamaged DNA (Friedberg 
et al., 2006). However, they can perform translesion syntheses with high accuracy on certain types of damaged templates (Tang et al., 2000). Y family polymerases such as the human Pol $\eta(\mathrm{XP}-\mathrm{V}$ Pol) can replicate UV-induced DNA lesions with relatively high fidelity (Kusumoto et al., 2004).

\subsection{Role of DinB in mutagenesis}

The Y-family proteins that belong to the DinB family involved in translesion synthesis are the most widespread and conserved. DinB family proteins can be found in all three kingdoms of life: bacteria, archaea, and eukaryotes (Ohmori et al., 2001). The E. coli DinB protein, encoded by dinP, was first isolated in 1995 (Ohmori et al., 1995). Later researchers discovered that $\operatorname{din} P$ is allelic to $\operatorname{din} B$, a damage-inducible gene identified 15 years earlier by Kenyon and Walker in 1980 (Kim et al., 1997). DinB is the fourth DNA polymerase identified in E. coli, and was termed DNA polymerase IV (Pol IV) (Wagner et al., 1999). The $\operatorname{din} B$ gene is part of an operon of four genes: $\operatorname{din} B, y a f N$, yafO, and yafP (Blattner et al., 1997). The molecular weight of DinB protein is 32,000 daltons, and its intrinsic polymerase activity has been demonstrated (Wagner et al., 1999). Around $250 \mathrm{DinB}$ molecules are found in each cell, and the number increases by 10-fold following SOS-induction (Kim et al., 2001). As mentioned in the previous section, $\operatorname{RecA}$ is a protein that plays an important part in the SOS regulatory network. It appears that the $\operatorname{din} B$ pathway does not require the RecA function once it is induced by the SOS response (Kim et al., 1997). However, recent studies showed that DNA damage inducible proteins, $\mathrm{UmuD}_{2}$ and $\mathrm{RecA}$, act in concert to modulate the mutagenic activity of 
DinB (Godoy et al., 2007).

The function of DinB is not clearly understood. DinB adds template-directed nucleotides in vitro in a distributive manner (Woodgate, 1999). It can efficiently extend a 3' primer terminus that is misaligned with a bulged template (Ohashi et al., 2000).

However, the replication product resulting from the translesion synthesis by DinB is one nucleotide shorter than expected. This finding is consistent with the $\operatorname{din} B$-dependent -1 frameshift events observed in vivo (Kim et al., 1997; Wagner et al., 1999; Ohashi et al., 2000).

The level of spontaneous mutagenesis in $E$. coli cell increases when $\operatorname{din} B$ is overexpressed (Strauss et al., 2000; Lenne-Samuel et al., 2002; McKenzie et al., 2001; Jacob et al., 2007). Overproduction of DinB leads to a dramatic increase in spontaneous $-1 \mathrm{G}$ frameshift mutations within a G6 cluster sequence (Kim et al., 1997). The DinB mutator effect shows that a $-1 \mathrm{G}$ event is 10 -fold more frequent than a $+1 \mathrm{G}$ event (Kim et al., 1997; Wagner et al., 2000). DinB overexpression includes an increase in base substitutions; with an obvious bias for substitutions towards GC base pairs, and about $70 \%$ of them occurred in $5^{\prime}-\mathrm{GX}-3^{\prime}$ sequences, where $\mathrm{X}$ represents the base ( $\mathrm{T}, \mathrm{A}$, or $\left.\mathrm{C}\right)$ that is mutated to G (Wagner et al., 2000). The base substitutions are predominately G:C $\rightarrow \mathrm{T}: \mathrm{A}$ (96-fold) transversions as compared to G:C $\rightarrow \mathrm{A}: \mathrm{T}$ (48-fold) transitions (Kim $e t$ al., 1997).

Another study showed that deletion of $\operatorname{din} B$ resulted in about a $75 \%$ decrease in spontaneous frameshift and base substitution mutations in $d n a E$ mutator strains containing an impaired Pol III (Strauss et al., 2000). A 1.5- to 3-fold reduction in $\operatorname{din} B$ - 
induced spontaneous mutagenesis was also found in a $\operatorname{din} E^{+}$control strain (Strauss et al., 2000). These findings suggest that some of the spontaneous mutations occurring in cells are due to the action of DinB.

In contrast, other studies suggest that $\operatorname{din} B$ does not contribute to spontaneous mutagenesis when it is expressed in basal levels in dividing cells (Tago et al., 2005; Kuban et al., 2005). Kuban et al. (2005) found that a lack of functional DinB did not significantly reduce the mutation frequencies in growing mismatch repair-deficient cells. This suggests that DinB does not contribute significantly to the normal chromosomal error rate (Kuban et al., 2005).

The aforementioned findings regarding the role of DinB in spontaneous mutagenesis are conflicting. McKenzie et al. (2003) attempted to resolve this conflict by finding that spontaneous mutagenesis is reduced by a polar $\operatorname{din} B$ allele, in which $\operatorname{din} B$ and the first few nucleotides of the neighboring yaf $N$ gene are deleted, but not by a nonpolar missense $\operatorname{din} B$ allele. It has been suggested that one or more of the genes downstream of $\operatorname{din} B$ may affect growth-dependent mutations (McKenzie et al., 2003). However, Kuban et al. (2005) studied the effect of the polar and nonpolar $\operatorname{din} B$ alleles on spontaneous mutagenesis with the same strains used in McKenzie's study (2003) and found no significant effect of either strain on spontaneous mutagenesis. Hence, the role of DinB in spontaneous mutagenesis remains elusive.

$\operatorname{din} B$ associated -1 frameshift mutagenesis was also found in adaptive mutagenesis (McKenzie et al., 2001; Tompkins et al., 2003), a type of spontaneous mutagenesis that can occur in bacteria during periods of prolonged stress in non-dividing or very slowly 
dividing populations (Hall, 1998). Pol IV is required for most adaptive point mutations, but apparently not for mutations in growing cells (McKenzie et al., 2001).

DinB was not found to be involved in UV mutagenesis (Courcelle et al., 2005). In another study, $\operatorname{din} B$ was shown to have a modest effect on UV mutagenesis. Deletion of dinB slightly reduced UV mutagenesis (Wrzesiński et al., 2005).

The $\operatorname{din} B$ gene is required for resistance to some DNA-damaging agents, that form adducts at the $\mathrm{N}^{2}$-position of deoxyguanosine (dG) (Jarosz et al., 2006). Although DinB has the potential -1 frameshift mutagenic activity, it can perform lesion bypass synthesis past $N^{2}$-deoxyguanosine adducts with great accuracy (Jarosz et al., 2006). It was shown that by mutating a single amino acid, such as the 'steric gate' residue of DinB (Phe13 $\rightarrow \mathrm{Val}$ ), the lesion-bypass polymerase would only replicate an undamaged template (Jarosz et al., 2006). DinB was found to be modestly efficient at replicating past $\mathrm{N}$ guanine-linked DNA-peptide cross-links upon exposure to an $\alpha, \beta$-unsaturated aldehyde, acrolein, and the incorporation of the correct nucleotide opposite the lesions is highly favored (Miǹko et al., 2008).

\subsection{Mutagenic function of $u m u D C$}

Earlier studies found that induction of two SOS genes, $u m u C$ and $u m u D$, is required for UV mutagenesis in E. coli (Kato and Shinoura, 1977). The umuDC genes encode a translesion DNA polymerase, DNA Pol V, in E. coli. The umuDC operon encodes both the $\mathrm{UmuD}$ and $\mathrm{UmuC}$ proteins. The gene less proximal from the $u m u D C$ operator is $u m u C$, and it produces a protein synthesized from an overlapping (1bp) reading frame 
(Perry et al., 1985). UmuC has a molecular weight of 45,000 daltons, and the UmuD protein is about 16,000 daltons (Elledge and Walker, 1983). In an uninduced cell, there are approximately $180 \mathrm{UmuD}$ molecules and an undetectable amount of UmuC protein. Once the SOS response is initiated, about 2,400 UmuD molecules and 200 molecules of UmuC are detected in a cell (Godoy et al., 2007). Pol V exhibits low processivity by adding six to eight nucleotides before dissociating from the replication site (Tang et al., 2000). In the presence of the non-hydrolyzable ATP $\gamma \mathrm{S}, \mathrm{Pol} V$ does not require the Pol III's processivity $\beta, \gamma$-complex for translesion synthesis (Tang et al., 2000). When copying undamaged DNA, Pol V shows low fidelity with error rates of about $10^{-3}$ to $10^{-4}$, while Pol IV is 5- to 10-fold more accurate (Tang et al., 2000).

Unlike DinB, UmuDC requires accessory proteins for translesion synthesis (Friedberg et al., 2006). RecA stabilizes UmuD by mediating the post-translational proteolytic processing that removes 24 amino acids from the $\mathrm{N}$-terminal of UmuD, thereby producing the UmuD' protein (Burckhardt et al., 1988; Nohmi et al., 1988). It was shown that RecA also directly stabilizes UmuD'. It does not appear that UmuC is directly stabilized by RecA, but it is dramatically stabilized in the presence of UmuD' (Frank et al., 1996). UmuD' has an active carboxyl terminal fragment that is required for SOS mutagenesis (Burckhardt et al., 1988; Shinagawa et al., 1988). UmuD' ${ }_{2} \mathrm{C}$ adds template-directed nucleotides in a distributive manner (Tang et al., 2000). Studies showed that purified $\mathrm{UmuD}_{2}{ }_{2} \mathrm{C}$ could not carry out translesion synthesis unless RecA was present (Tang et al., 2000). The effects of RecA protein on Pol V caused a 15,000-fold increase in DNA synthesis efficiency (Tang et al., 2000). In another study, a purified 
MalB-UmuC chimeric protein was shown to be capable of carrying out translesion synthesis when $\mathrm{UmuD}_{2}{ }_{2}, \mathrm{RecA}$, and SSB (single-stranded DNA binding protein) were all present (Reuven et al., 1999). The presence of RecA and SSB increased $\mathrm{UmuD}_{2} \mathrm{C}$ activity by 340 - and 1040-fold, respectively (Pham et al., 2001). The MalB-UmuC chimeric protein alone could carry out limited DNA synthesis on undamaged template DNA (Reuven et al., 1999).

Like other Y-family polymerases, $\mathrm{UmuD}_{2} \mathrm{C}$ lacks proofreading activity and possesses lower fidelity. The observed mutation rate was 41-fold higher than Pol III holoenzyme (Maor-Shoshani et al., 2000). However, $\mathrm{UmuD}_{2}^{\prime} \mathrm{C}$ bypasses a site-directed abasic (loss of pyrimidine) lesion with an efficiency of about 100- to 150-fold higher than the Pol III holoenzyme complex (Tang et al., 1999). Mutations in umuC and/or umuD reduce UV mutability by more than 100-fold and slightly reduce UV sensitivity (Tang et al., 2000). Additional evidence came from translesion synthesis over three well-studied lesions: a cis-syn thymine-thymine photodimer, a thymine-thymine (6-4) photoproduct, and an abasic (apurinic / apyrimidinic) site, suggesting that Pol V is indeed responsible for most SOS mutagenesis (Tang et al., 2000). A mutagenic characteristic of Pol V is that it incorporates guanine opposite the $3^{\prime}$-thymine of a TT (6-4) photoproduct (Tang et al., 2000). $\mathrm{UmuD}_{2}^{\prime} \mathrm{C}$ preferentially incorporates an adenine opposite the $3^{\prime}$ pyrimidine of a thymine-thymine cis-syn photodimer and opposite abasic sites (Tang et al., 2000). The $r e c A$ and $u m u C$ genes are also involved in spontaneous base-pair substitution mutagenesis (Bhamre et al., 2001). 


\subsection{The roles of Pol II in replication restart and translesion synthesis}

Pol II, a B-family polymerase, was discovered in 1970 (Rangarajan et al., 1999). It synthesizes DNA accurately due to its $3^{\prime}$ to $5^{\prime}$ exonuclease (proofreading) activity (Cai et al., 1995). Its polymerase activity is increased sevenfold in response to DNA damage induced by UV irradiation (Bonner et al., 1988). Upon SOS induction, the number of Pol II molecules in a cell is increased from 50 to 350 (Qiu and Goodman, 1997). Pol II is encoded by the $\operatorname{din} A$ gene, also known as polB, that is regulated transcriptionally by the LexA repressor (Qiu and Goodman, 1997). The absence of Pol II in a cell does not exhibit any adverse effect upon UV survival unless pol $\mathrm{V}$ is also missing (Rangarajan et al., 1999). Double mutants of Pol II and Pol V show approximately 2- to 3-fold more UV sensitivity than Pol V mutants (Rangarajan et al., 1999). Pol II plays a pivotal role in replication restart. Replication restart is a DNA damage recovery phenomenon. Following DNA damage-induced transient partial inhibition of DNA synthesis, DNA synthesis recovers to its predamage rate in about 30 to 45 min (Friedberg et al., 2006). Deletion of polB impairs the ability for the cell to carry out replication restart (Rangarajan et al., 1999). Pol II is induced within one minute upon UV exposure, while the induction of Pol V occurs 45 min after UV irradiation (Sommer et al., 1998; Goodman, 2007). Pol II copies the correct information from the uncoupled nascent lagging strand formed during the RecA nucleoprotein-mediated regression. The lesion is bypassed accurately by Pol II. The post-UV DNA synthesis in cells that lack Pol II is delayed significantly and the synthesis depends on $\mathrm{UmuD}_{2} \mathrm{C}$ (Rangarajan et al., 1999). It appears that both Pol II-dependant and Pol V-dependant replication restart also require 
Pol III (Rangarajan et al., 1999). Replication restart occurs around 90-100 min post-UV in the double Pol II and Pol V mutant, which indicates that there are at least three genetically independent pathways of replication restart (Rangarajan et al., 1999).

Pol II is used for translesion synthesis in copying abasic lesions in the absence of induction of the GroEL ${ }^{+} \mathrm{S}^{+}$heat shock proteins (Tessman and Kennedy, 1994). These heat shock proteins are chaperones that help stabilize the UmuC protein needed for SOS repair. This might in turn increase the formation of functional UmuC complexes and eliminate the need for Pol II (Tessman and Kennedy, 1994).

\subsection{Modulation of function by protein-protein interactions}

It is unclear how the cell manages its numerous DNA polymerases and determines which enzyme gains access to the primer terminus. It appears that in E. coli, expression of DNA polymerases II, IV and V is increased after the induction of SOS response due to DNA damage. This indicates that part of the control system is at the transcription level (Friedberg et al., 2006). The activity of Pol V is controlled at the post-translational level. The activity of UmuC also depends on the form of UmuD present in the substrate. UmuD must be cleaved to UmuD' in order for UmuC to function as a DNA polymerase (Friedberg et al., 2006).

The interactions between UmuD and RecA in regulating $u m u C$-dependent mutagenesis have been thoroughly studied in the past 30 years (Friedberg et al., 2006). As described in the previous section, $u m u D$ and $u m u C$ share the same operon. The umuDC gene products play two unique and temporally distinct roles in DNA damage 
tolerance (Sutton et al., 1999). UmuD and $\mathrm{UmuD}_{2}$ proteins interact not only with the $\beta$ processivity clamp but also with the $\alpha$ (catalytic) and $\varepsilon$ (proofreading) subunits of Pol III (Sutton et al., 1999). Interestingly, $\mathrm{UmuD}_{2}$ and $\mathrm{UmuD}_{2}^{\prime}$ interact differently with the $\beta$ and $\alpha$ subunits. UmuD, which is associated with the DNA checkpoint, interacts more strongly with the $\beta$ subunit than with the $\alpha$ alpha subunit. In contrast, UmuD' protein, the cleaved form of UmuD, associated with mutagenesis and translesion synthesis, interacts more strongly with the $\alpha$ subunit than then the $\beta$ subunit (Sutton et al., 1999). The study performed by Opperman et al. (1999) suggested that UmuD and UmuC delayed the resumption of DNA replication to allow nucleotide excision repair additional time to repair the damage accurately before replication is resumed. If the lesion cannot be fixed in about $20 \mathrm{~min}$, the ssDNA:RecA nucleoprotein filament induces the autoproteolytic process of UmuD, and UmuD' becomes the predominant form available to interact with UmuC (Opperman et al., 1999; Burckhardt et al., 1988). UmuD'2 and RecA are required for UmuC to perform translesion synthesis (Tang et al., 1999; Reuven et al., 1999). UmuC, UmuD, and RecA are believed to function in concert with the replicative polymerase, the Pol III holoenzyme (Friedberg et al., 2006).

When Pol IV (Din B) interacts with the $\beta, \gamma$-complex of the DNA Pol III, the efficiency of translesion synthesis is increased by 3,000-fold (Lenne-Samuel et al., 2002; Tang et al., 2000). Lenne-Samuel et al. (2002) identified the extreme C-terminal peptide of DinB as being essential for the interaction with the $\beta$ clamp. If the $\mathrm{C}$-terminal peptide of DinB is mutated, it cannot participate in error-free or frameshift mutagenic translesion synthesis (Lenne-Samuel et al., 2002). DinB was found to be responsible for detaching 
Pol III from the $\beta$-clamp when Pol III idled at the replicative fork in vitro (Furukohri et al., 2008). A recent study has shown that Pol IV is able to slow replication fork progression with the authors concluding that this may allow time for lesions to be removed by excision repair before the fork reaches them (Indiani et al., 2009). DinB has a concentration-dependent inhibitory effect on a moving Pol III in catalyzing rapid chain elongation on the template (Uchida et al., 2008). The inhibitory effect of DinB does not seem to require the presence of its $\beta$-binding motif and its polymerase activity (Uchida $e t$ al., 2008). This suggests that DinB has at least two distinct roles: translesion synthesis and inhibiting Pol III at the replication fork.

Recently, it has also been shown that UmuD, UmuD', and RecA acting together also regulate both the activity and the mutagenic properties of DinB through proteinprotein interactions (Godoy et al., 2007). The ternary complex of UmuD, RecA, and DinB was isolated and was stable on the minute timescale (Godoy et al., 2007). The study showed that DinB-dependent -1 frameshift mutagenesis could be suppressed by the co-overproduction of UmuD. A noncleavable UmuD variant completely suppressed DinB-dependent -1 frameshift mutagenesis (Godoy et al., 2007). The DinB-binding deficient UmuD variant can perform RecA-mediated autoproteolysis, but cannot reduce DinB-dependent -1 frameshift mutagenesis (Godoy et al., 2007). When additional RecA and $\mathrm{UmuD}_{2}$ are added to an assay in which $\mathrm{DinB}$ replicates a template, it results in a remarkable increase in DinB catalytic proficiency with a properly paired terminus. It appears that $\mathrm{UmuD}_{2}$ and $\mathrm{RecA}$ modulate the mutagenic potential of DinB by enclosing its open active site (Godoy et al., 2007). 


\section{MATERIALS AND METHODS}

\subsection{Bacterial strains}

The E. coli strains and $\operatorname{trp} A$ mutants used in this study are presented in Table 1.

Table 1. Escherichia coli strains used in this study

\begin{tabular}{|c|c|c|}
\hline Strain & Relevant genotype & Source \\
\hline KD1094 & $\operatorname{trp} A 223$, arg, leu, his, thr & Cox et al., 1972 \\
\hline SR1282 & $\operatorname{trp} A 540$ & Sargentini and Smith, 1987 \\
\hline SR1284 & $\operatorname{trp} A 9813$ & Sargentini and Smith, 1987 \\
\hline KD1093 & $\operatorname{trp} A 78$, arg, leu, his, thr & Cox et al., 1972 \\
\hline KD1092 & $\operatorname{trp} A 58$, arg, leu, his, thr & Cox et al., 1972 \\
\hline KD1117 & $\operatorname{trpA11}$ & Yanofsky and Crawford, 1972 \\
\hline YG7207 & $\begin{array}{l}\Delta(\operatorname{din} B-y a f N):: \operatorname{kan}^{\mathrm{R} a} \text { derivative of } \\
\mathrm{AB} 1157\end{array}$ & Kim et al., 1997 \\
\hline RW82 & $\begin{array}{l}\triangle u m u D C 595:: \text { cat derivative of } \\
\mathrm{AB} 1157\end{array}$ & Woodgate, 1992 \\
\hline $\mathrm{AB} 1157$ & $\begin{array}{l}\mathrm{F}^{-} \text {thr-1 leuB6 proA2 his4 thil argE3 } \\
\text { lacY1 galK2 rpsL supE44 ara-14 xyl- } \\
15 \text { mil-1, txs-33 }\end{array}$ & Sargentini and Smith, 1989 \\
\hline SMR5830 & $\begin{array}{l}\text { SMR } 4562 \operatorname{din} B 10\left[\mathrm{~F}^{\prime} \operatorname{din} B 10\right. \\
\left.\text { proAB }^{+} \text {lac133SlacZ }\right]^{\mathrm{b}}\end{array}$ & Rosenberg et al., 2003 \\
\hline SMR4562 & $\begin{array}{l}\Delta(\text { lac-proAB })_{\mathrm{XIII}} \text { thi ara } \mathrm{Rif}^{\prime}\left[\mathrm{F}^{\prime} \operatorname{din} B^{+}\right. \\
\left.\text {pro } A B^{+} \text {lacI33 } \Omega \operatorname{lac} Z\right]\end{array}$ & Rosenberg et al., 2003 \\
\hline RF01 & $\operatorname{trp} A 223 \operatorname{din} B$ & KD1094 x P1virA YG7207 \\
\hline RF02 & $\operatorname{trp} A 223$ umuC & KD1094 x P1virA RW82 \\
\hline RF03 & $\operatorname{trp} A 223 \operatorname{din} B$ umuC & $\mathrm{RF} 02 \times P 1$ virA RW82 \\
\hline RF04 & $\operatorname{trp} A 540 \operatorname{din} B$ & SR1282 x PlvirA YG7207 \\
\hline RF05 & $\operatorname{trp} A 9813 \operatorname{din} B$ & SR1284 x PlvirA YG7207 \\
\hline RF06 & $\operatorname{trp} A 11 \operatorname{din} B$ & KD1117 x PlvirA YG7207 \\
\hline RF07 & $\operatorname{trp} A 58 \operatorname{din} B$ & KD1092 x PlvirA YG7207 \\
\hline RF08 & $\operatorname{trp} A 78 \operatorname{din} B$ & KD1093 x P1virA YG7207 \\
\hline
\end{tabular}




\subsection{Media}

Minimal medium (MM) plates contain Vogel-Bonner salts (Vogel and Bonner, 1956), solidified with $1.5 \%$ agar (Difco Laboratories), and supplemented with $0.2 \%$ glucose, vitamin B1 and $50 \mu \mathrm{g} / \mathrm{ml}$ of amino acids. LB (Luria-Bertani) broth consists of $1 \%$ tryptone, $0.5 \%$ yeast extract and $0.5 \% \mathrm{NaCl}$. Tryptone plates consist of $1 \%$ tryptone and $0.5 \% \mathrm{NaCl}$ solidified with $1.5 \%$ agar. Transductants were selected on tryptone plates containing kanamycin. The saline for dilutions and washing was $0.85 \% \mathrm{NaCl}$. Soft LCTG agar consists of $1 \%$ tryptone, $0.5 \% \mathrm{NaCl}, 0.5 \%$ yeast extract, $0.1 \%$ glucose, and solidified with $0.65 \%$ agar. LCTG plates contain $5 \%$ tryptone, $2.5 \% \mathrm{NaCl}, 2.5 \%$ yeast extract, $0.5 \%$ glucose, and solidified with $7.5 \%$ agar. The LCTG medium was supplemented with $5 \mathrm{mM} \mathrm{CaCl} 2$ and $0.25 \%$ of thymidine.

\subsection{Lysate preparation}

P1 lysates were prepared for the $u m u C$ and $\operatorname{din} B \Delta$ (YG7207) donor strains. Soft LCTG agar was microwaved for $30 \mathrm{sec}$ and kept in a $60{ }^{\circ} \mathrm{C}$ water bath. $3 \mathrm{ml}$ aliquots were made for each donor strain. The donor strain $(100 \mu \mathrm{l})$ and phage $(5 \mu \mathrm{l})(\mathrm{P} 1$ virA $)$ were added to each aliquot, and mixed. The mixture was then pored onto freshly made LCTG plates and kept at $65^{\circ} \mathrm{C}$ for $5 \mathrm{~min}$. Control plates were made for each donor strain by spreading $100 \mu \mathrm{l}$ of the donor strain without phage onto the LCTG plate. The plates were incubated at $37^{\circ} \mathrm{C}$ for 24 to $48 \mathrm{hr}$. If there was bacterial growth on the plates after incubation, the soft agar layer was scraped off, rinsed with $3 \mathrm{ml}$ of $\mathrm{LB}$ and $5 \mathrm{mM} \mathrm{CaCl}_{2}$, and transferred to a test tube. Four drops of chloroform was added to each tube. The 
tube was then centrifuged for $15 \mathrm{~min}$ at full speed. The supernatant was then collected and transferred into a glass tube, and $70 \mu \mathrm{l}$ of chloroform was added. The supernatant was store at $5^{\circ} \mathrm{C}$ or used immediately for transduction.

\subsection{Transductions}

P1 transductions were carried out to transfer the dinB $\triangle$ allele into KD1094

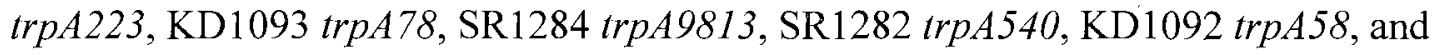
KD1117 $\operatorname{trp} A 11$. Strains $\operatorname{trp} A 223 \operatorname{din} B \triangle u m u C$ and $\operatorname{trp} A 223 u m u C$ were constructed by P1 transduction using donor strain RF01 trpA223 dinB and KD1094 trpA223, respectively. The transductions were done according to the protocol described by Lennox (1955). The recipient strains were grown to saturation in $5 \mathrm{ml}$ of L-broth. $200 \mu \mathrm{l}$ of $30 \mathrm{mM} \mathrm{MgSO}_{4}$ and $15 \mathrm{mM} \mathrm{CaCl}_{2}, 200 \mu \mathrm{l}$ of recipient strain, and $25 \mu \mathrm{l}$ of lysate were mixed in an Eppendof tube and incubated at $37^{\circ} \mathrm{C}$ for $20 \mathrm{~min}$. It was then centrifuged for 1-2 min, and the supernatant was discarded afterwards. The pellet was resuspended with $0.1 \mathrm{ml}$ of 1x Vogel-Bonner salts (Vogel and Bonner, 1956). The mixture was spread onto kanamycin plates to select for $\operatorname{din} B \triangle$ transductants, and onto chloramphenicol plates to select for $u m u C$ transductants. Control plates were prepared by spreading the lysate and recipients on the antibiotic plates separately.

\subsection{UV survival of $\operatorname{din} B \Delta$}

All four strains, $\operatorname{din} B^{+} u m u C^{+}, \operatorname{din} B^{+} u m u C, \operatorname{din} B \Delta u m u C^{+}$, and $\operatorname{din} B \Delta u m u C$, were used in a 20-hour survival study to determine their ability to survive after UV irradiation. The $\operatorname{din} B \Delta$ mutant in this study had a polar mutation, where most of the $\operatorname{din} B$ 
gene and the first part of the downstream YafN gene are deleted. An overnight culture was made for each strain in $5 \mathrm{ml} \mathrm{L}$-broth; $1 \mathrm{ml}$ of the overnight culture was then added to $50 \mathrm{ml}$ of fresh $\mathrm{L}$-broth and incubated at $37^{\circ} \mathrm{C}$ in a shaker.

For UV survival, a $5 \mathrm{ml}$ aliquot of the bacterial culture was collected every 30 min, washéd, resuspended in $500 \mu \mathrm{l}$ of $0.85 \%$ saline, and spread onto two tryptone plates to titer the total number of surviving cells. One of the tryptone plates was exposed to UV irradiation at $25 \mathrm{~J} / \mathrm{m}^{2}$ for $60 \mathrm{sec}$ and then wrapped in aluminum foil, and the other was unexposed. The tryptone plates were incubated at $37^{\circ} \mathrm{C}$ overnight and then the resulting total cells were counted. The percent survival was calculated by dividing the average number of cells that survived the UV-irradiation on the tryptone plate by the average number of cells found on the non-irradiated tryptone plate. The growth curves for all four strains (Fig. 1) were constructed by measuring the absorbance of the bacterial culture every $30 \mathrm{~min}$ at $550 \mathrm{~nm}$ (Jenway 6405 Spectrophotometer, Jenway, England).

\subsection{UV survival of $\operatorname{din} B 10$}

The strain $\operatorname{din} B 10$ (SMR5830) contains a nonpolar $\operatorname{din} B$ missense mutation that does not affect the downstream genes YafN, YafO, and YafP (McKenzie et al., 2003). An overnight culture was made for the $\operatorname{dinB10}$ strain and an isogenic $\operatorname{din} B^{+}$(SMR4562) strain in $5 \mathrm{ml} \mathrm{L}$-broth; $1 \mathrm{ml}$ of the overnight cultures were then added to $50 \mathrm{ml}$ of fresh L-broth and incubated at $37^{\circ} \mathrm{C}$ in a shaker. $5 \mathrm{ml}$ aliquots of the bacterial cultures were collected between one to three hours of incubation, washed, re-suspended in $500 \mu \mathrm{l}$ of $0.85 \%$ saline, and spread onto two tryptone plates for each strain. One of the tryptone plates was 
exposed to UV irradiation at $25 \mathrm{~J} / \mathrm{m}^{2}$ for $60 \mathrm{sec}$ and then wrapped in aluminum foil, and the other was not exposed. The tryptone plates were incubated at $37^{\circ} \mathrm{C}$ for $24 \mathrm{hrs}$ and then the resulting cells were counted. The percent survival was calculated by dividing the number of cells that survived the UV irradiation by the number of cells found on the non-irradiated tryptone plate.

\subsection{UV-induced mutagenesis of $\operatorname{trp} A 223$ and $\operatorname{trp} A 78$}

The $\operatorname{Trp}^{+}$reversion frequency was measured by inoculating individual colonies from each of the $\operatorname{trp} A 223$ and $\operatorname{trp} A 78$ strains in $5 \mathrm{ml}$ of L-broth and incubating at $37^{\circ} \mathrm{C}$ for 24 or $48 \mathrm{hr}$. The cells were then concentrated and washed by centrifugation and resuspended with $500 \mu \mathrm{l}$ of $0.85 \%$ saline. Serial dilutions were made and were plated on minimal media without tryptophan to select for $\operatorname{Trp}^{+}$revertants. Tryptone plates were used to titer for total cells. Three to six plates were exposed to $25 \mathrm{~J} / \mathrm{m}^{2} \mathrm{UV}$ light from a Sylvania germicidal lamp at $254 \mathrm{~nm}$. The other plates were not exposed to UV light to detect any reversion due to spontaneous mutagenesis. Irradiated plates were wrapped in aluminum foil to prevent photorepair. The minimal medium plates were incubated for 4 to 5 days at $37^{\circ} \mathrm{C}$ and the number of revertants was determined by counting the resulting colonies. The tryptone plates were incubated overnight and the resulting colonies counted. The $\operatorname{Trp}^{+}$revertants were purified by restreaking each revertant colony on the same medium. The colonies that did not grow on the new minimal medium plate were assumed to be not true revertants and subtracted from the original revertant counts. The number of UV-induced revertants per $10^{8}$ surviving cells was calculated by subtracting 
the average number of $\operatorname{Trp}^{+}$revertants on the irradiated plates by the average number of $\operatorname{Trp}^{+}$revertants per non-irradiated plate and dividing the result by the average titer of cells that survived the irradiation.

\subsection{Spontaneous mutagenesis and reversion frequencies}

Spontaneous mutation frequencies were determined for each strain in both wildtype $\left(\operatorname{din} B^{+}\right)$and $\operatorname{din} B \Delta$ and $u m u C$ backgrounds. Overnight cultures were made from a small inoculum and grown to saturation at $37^{\circ} \mathrm{C}$ in L-broth. The cells were washed in saline, diluted when appropriate, and $0.1 \mathrm{ml}$ of samples of each culture spread on minimal plates without tryptophan to determine the number of revertants found in each strain. The number of total cells was determined by plating on tryptone plates. The reversion frequencies were calculated by dividing the average number of revertants by the average number of total cells.

\subsection{PCR amplification of the $t r p^{+}$gene}

Direct DNA sequencing was performéd to determine the changes in the nucleic acid sequence that gave the $\operatorname{trp} A 223$ revertants the $\operatorname{Trp}^{+}$phenotype. The DNA of each strain was isolated by suspending a single colony in $30 \mu \mathrm{l}$ of sterile water in an Ependorff tube. The tubes were placed in a boiling water bath for $2 \mathrm{~min}$ and were frozen at $-70{ }^{\circ} \mathrm{C}$. The samples were then centrifuged for 2 min. The supernatant was collected which contained the DNA. For each strain, $5 \mu 1$ of the template DNA and $20 \mu 1$ of the master mix were mixed in an Ependorff tube. The control for the PCR (Polymerase Chain Reaction) contained $5 \mu \mathrm{l}$ of $\mathrm{H}_{2} 0$ and $20 \mu \mathrm{l}$ of the master mix. The master mix for PCR 
contained 1x PCR buffer, $1.5 \mathrm{mM}$ magnesium ion, $0.2 \mathrm{mM}$ dNTPs, $0.25 \mu \mathrm{M}$ of forward primer, $0.25 \mu \mathrm{M}$ of reverse primer, and $0.04 \mathrm{U} / \mathrm{ml}$ of taq polymerase. The forward and reverse primers specific for the $\operatorname{trp} A$ alleles and their revertants within the $\operatorname{trp} A$ gene were 5'-GATCCGGGCATTGAGCAGTCA-3' and 3'-CATGTTGGCTACTTTCGCCGC-5', respectively. The PCR product of 717 base-pairs was cleaned using ExoZap (USB Corporation, Cleveland, $\mathrm{OH}$ ). The concentration and purity of the DNA was measured using a nanodrop spectrophotometer (NanoDrop, ThermoScientific, Willmington, DE). The PCR product at $60-80 \mathrm{ng} / \mu 1$ was transferred into a new 96 well plate for DNA sequencing (Polymorphic DNA Technologies, Alameda, CA). The DNA sequencing results were analyzed by performing a multiple sequence alignment against the $E$. coli $\operatorname{trp} A$ gene sequence and the $\operatorname{trp} A 223$ sequence using ClustalW. 


\section{RESULTS}

\subsection{Growth curves}

The 20 hour growth curves for the $\operatorname{din} B^{+} u m u C^{+}, \operatorname{din} B^{+} u m u C, \operatorname{din} B \Delta u m u C^{+}$, and $\operatorname{din} B \triangle u m u C$ strains are shown in Fig. 1. All four strains had similar growth curves and entered log phase before $30 \mathrm{~min}$ and then started to enter stationary phase at about 360 to $400 \mathrm{~min}$.

\subsection{Cell survival in $U V$-exposed $\operatorname{din} B \Delta$ and $u m u C$ strains in a 20-hour growth period}

20 hour UV survival curves were determined for four strains, $\operatorname{din} B^{+} u m u C^{+}$(wildtype), $\operatorname{din} B^{+} u m u C, \operatorname{din} B \Delta u m u C^{+}$, and $\operatorname{din} B \Delta u m u C$ and are shown in Fig. 2. The percentage of surviving bacteria was measured at UV fluences of $25 \mathrm{~J} / \mathrm{m}^{2}$. The wild-type strain maintained a similar level of UV resistance throughout the 20 hours. The $\operatorname{din} B \Delta$ $u m u C^{+}$stain was highly sensitive to UV damage for the first three hours of growth, and then became more resistant as the growth curve reached seven or eight hours. The $\operatorname{din} B^{+} u m u C$ and $\operatorname{din} B \Delta u m u C$ strains had very similar low levels of UV survival throughout the 20 hour period (Fig. 2). There was some increase in UV resistance toward the end of the growth period but it remained lower than $u m u C^{+}$levels.

\subsection{The effect of $\operatorname{din} B 10$ on $\mathrm{UV}$ survival}

The UV survival of a $\operatorname{din} B$ strain with a nonpolar mutation, $\operatorname{din} B 10$, was determined. The $\operatorname{din} B 10$ strain had a similar survival level after UV damage compared to 
an isogenic wild-type strain (SMR4562) at the early growth stage (2-3 hr). In contrast, the polar $\operatorname{din} B \triangle$ allele is 100 -fold more sensitive to UV damage compared to the nonpolar $\operatorname{dinB10}$ strain and the wild-type strain (Fig. 3).

\subsection{UV-induced mutagenesis and spontaneous mutagenesis}

In order to understand the role of the $\operatorname{din} B$ allele in UV mutagenesis, UV-induced $\operatorname{Trp}^{+}$reversion frequencies for the $\operatorname{trp} A 223$ and $\operatorname{trp} A 78$ alleles were measured in wild-type and $\operatorname{din} B \Delta$ strains. The results are shown in Table 2. It appears that $\operatorname{din} B$ has little or no effect on UV-induced mutagenesis with the trpA223 allele. There was a small increase in the $\operatorname{Trp}^{+}$reversion frequency with the $\operatorname{trp} A 78$ allele in the $\operatorname{din} B \Delta$ strain.

The spontaneous $\operatorname{Trp}+$ reversion frequencies are shown in Table 3. For both the $\operatorname{trp} A$ base-pairs substitution and frameshift alleles, there appears to be little effect of the $\operatorname{din} B \Delta$ allele on spontaneous mutagenesis. There was a very small decrease in $\operatorname{trp} A 223$ $\operatorname{Trp}^{+}$reversion frequencies for both the $\operatorname{din} B \Delta$ and $u m u C$ strains. The $u m u C$ mutant has the same level of spontaneous mutagenesis as the $u m u C \operatorname{din} B$ double mutant as shown in Table 3. Neither $u m u C$ nor $\operatorname{din} B$ is contributing significantly to spontaneous mutagenesis in our assay.

\subsection{Characterization and distribution of spontaneous $\operatorname{Trp}^{+}$revertants}

The characterization and the distribution of the revertants are shown in Table 4. The presence of $\operatorname{din} B \Delta$ appears to reduce the presence of A:T $\rightarrow$ G:C transitions while umuC eliminated $\mathrm{A}: \mathrm{T} \rightarrow \mathrm{T}: \mathrm{A}$ transversions in the $u m u C \operatorname{din} B^{+}$strain but only slightly 
reduced them in the $u m u C \operatorname{din} B \Delta$ strain. $\mathrm{A}: \mathrm{T} \rightarrow \mathrm{G}: \mathrm{C}$ transitions occur less frequently than $\mathrm{A}: \mathrm{T} \rightarrow \mathrm{C}: \mathrm{G}$ transversions in all strains. 


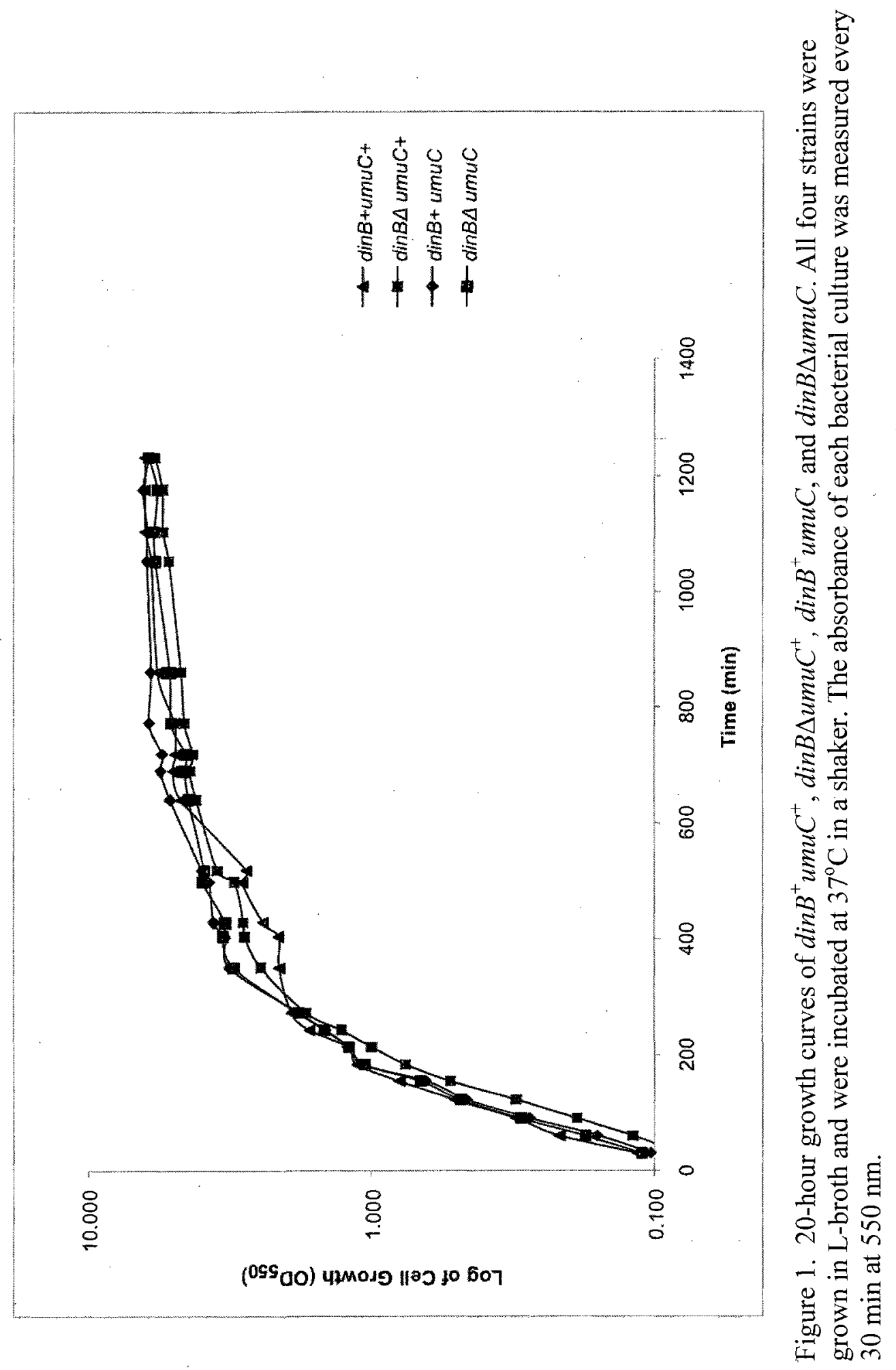




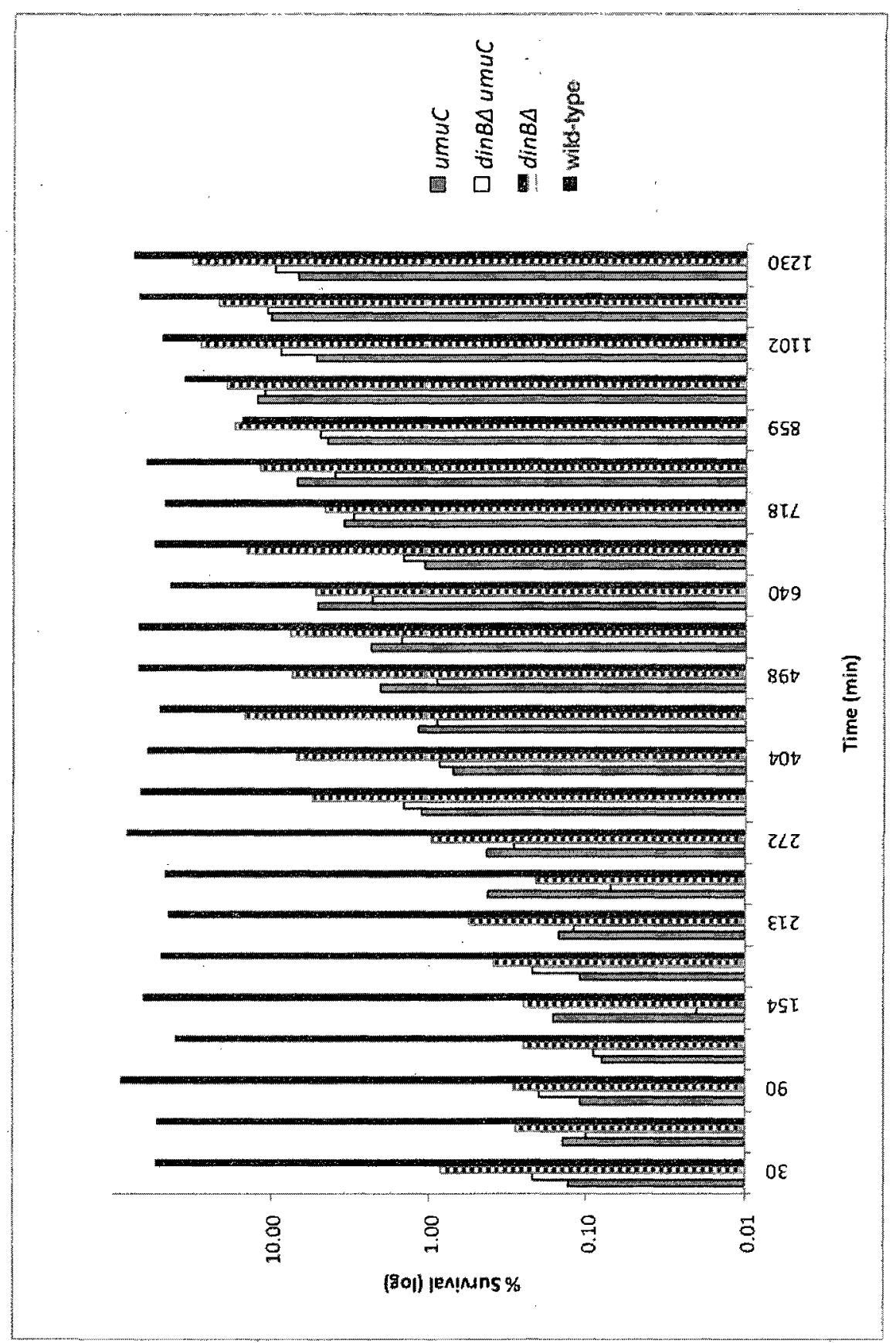




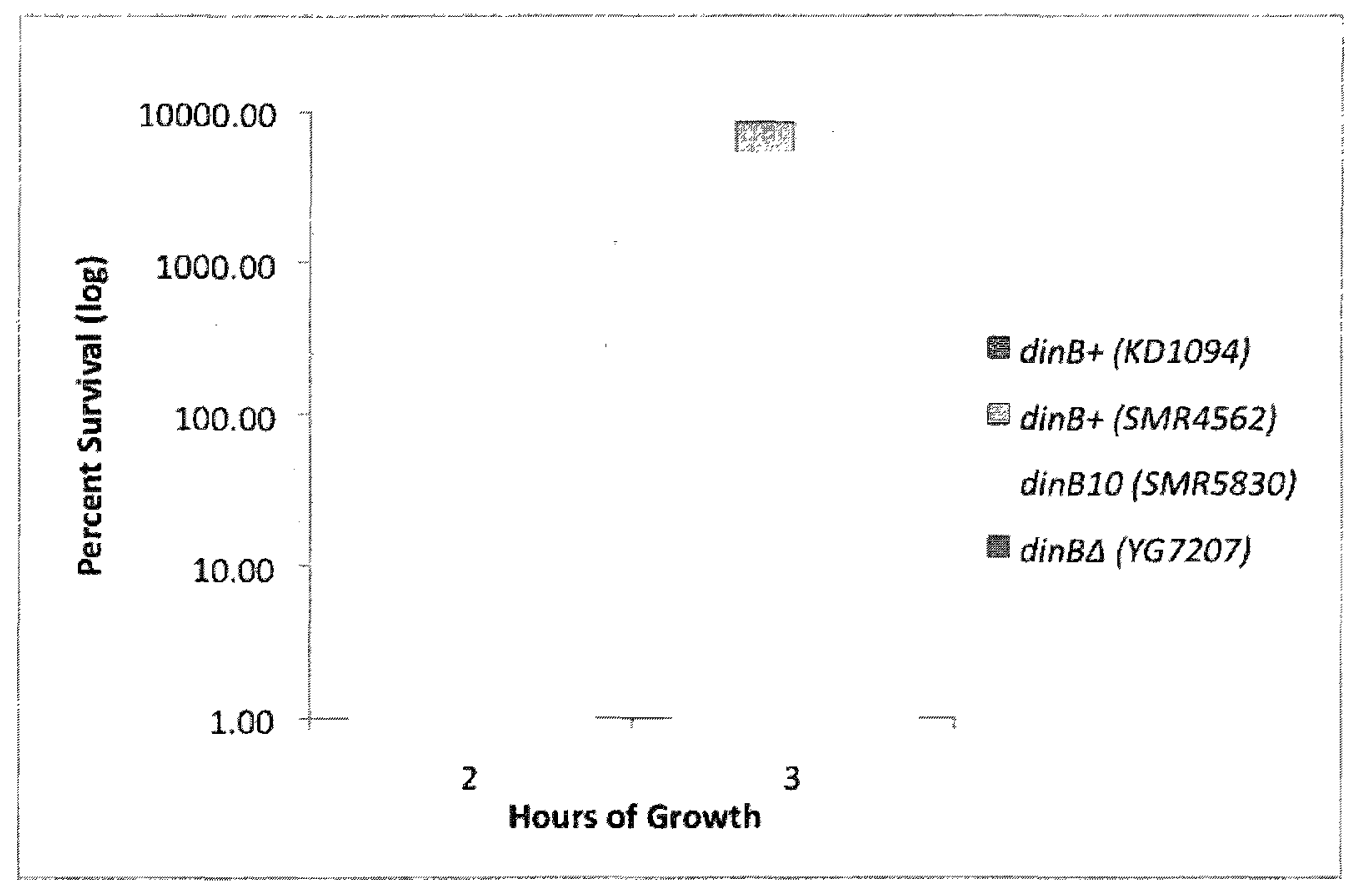

Figure 3. The comparison of UV survival of the polar and nonpolar $\operatorname{din} B$ strains with wild-type strains. All strains are exposed to a fluence of $25 \mathrm{~J} / \mathrm{m}^{2}$ of UV. 


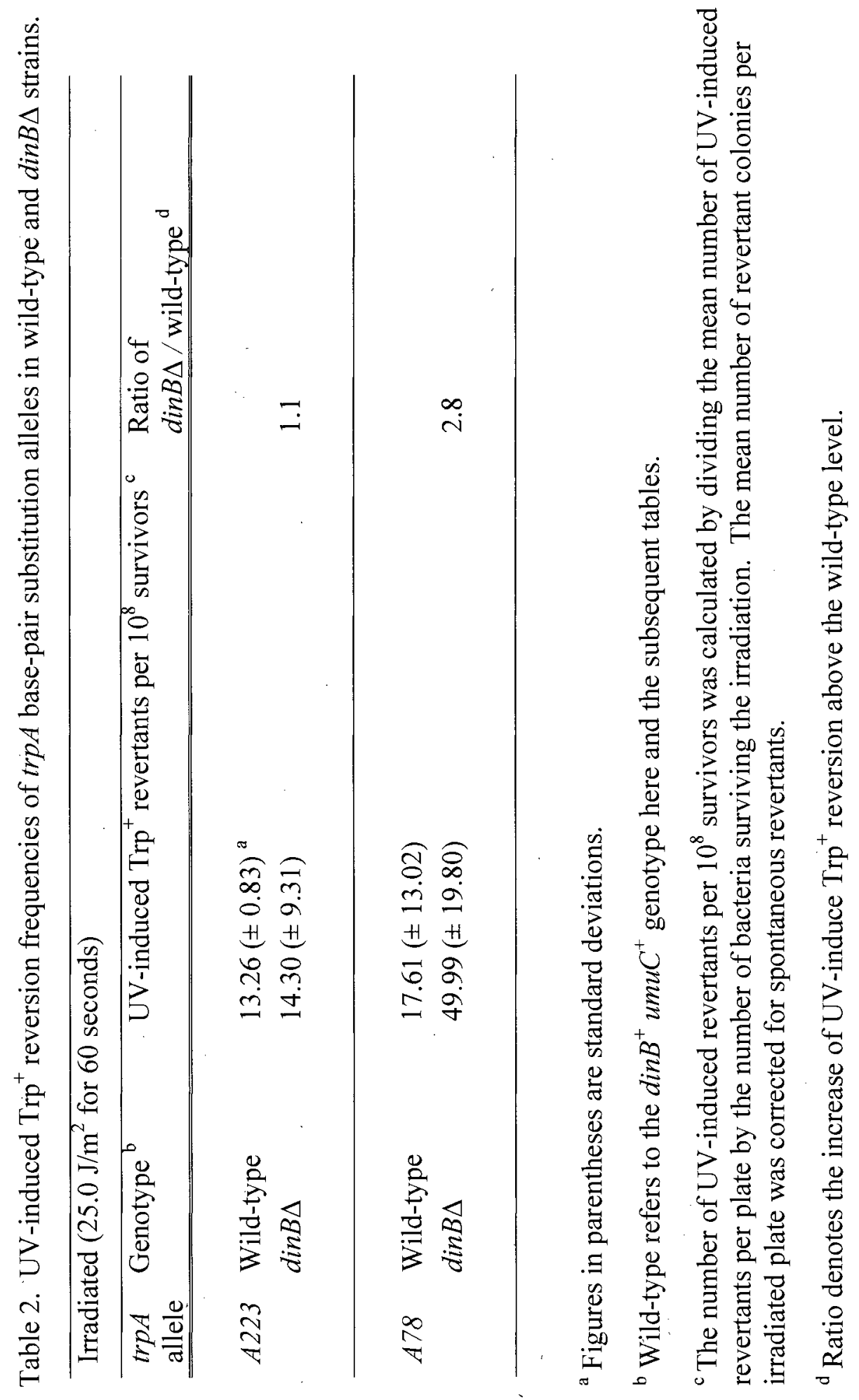




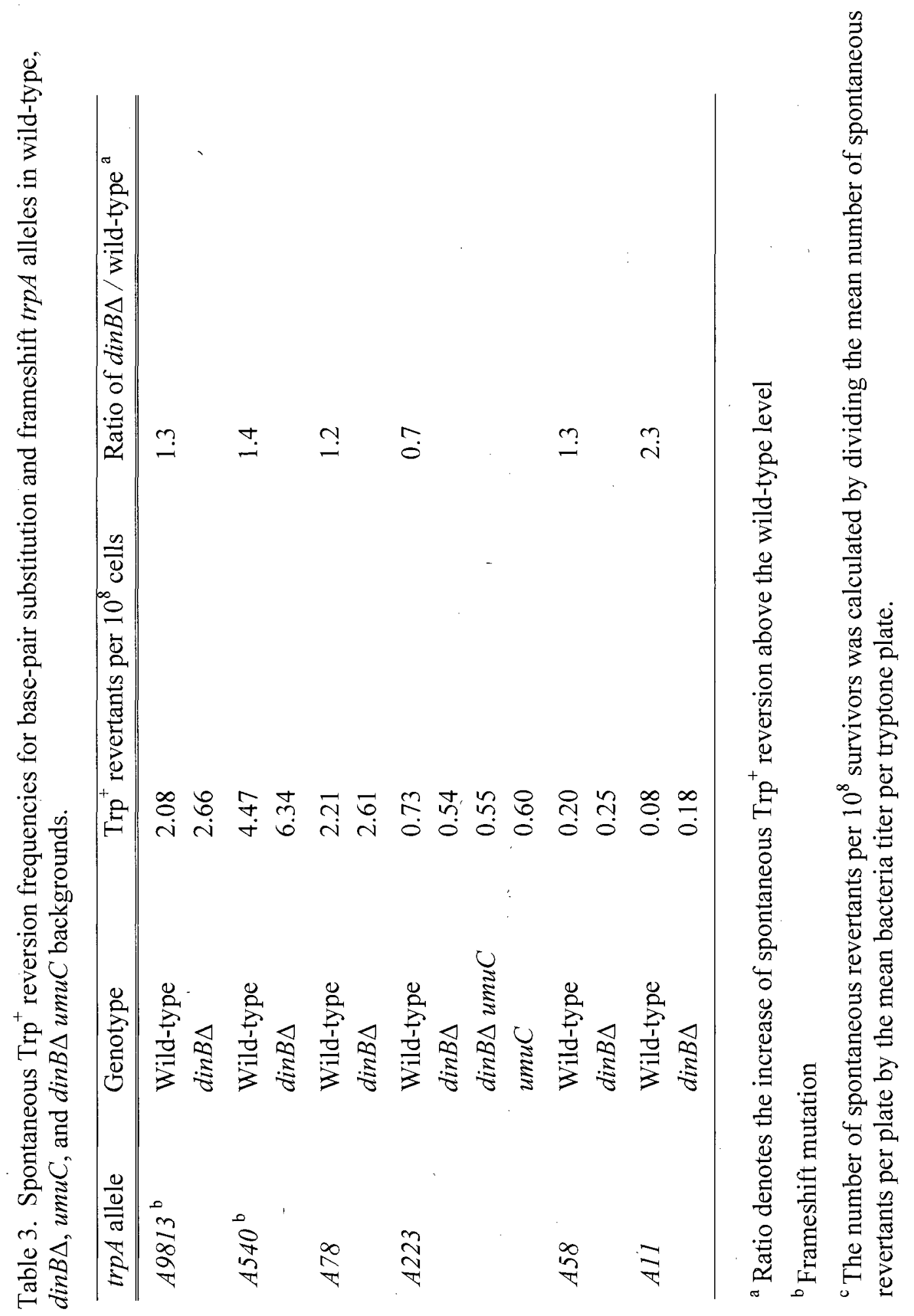




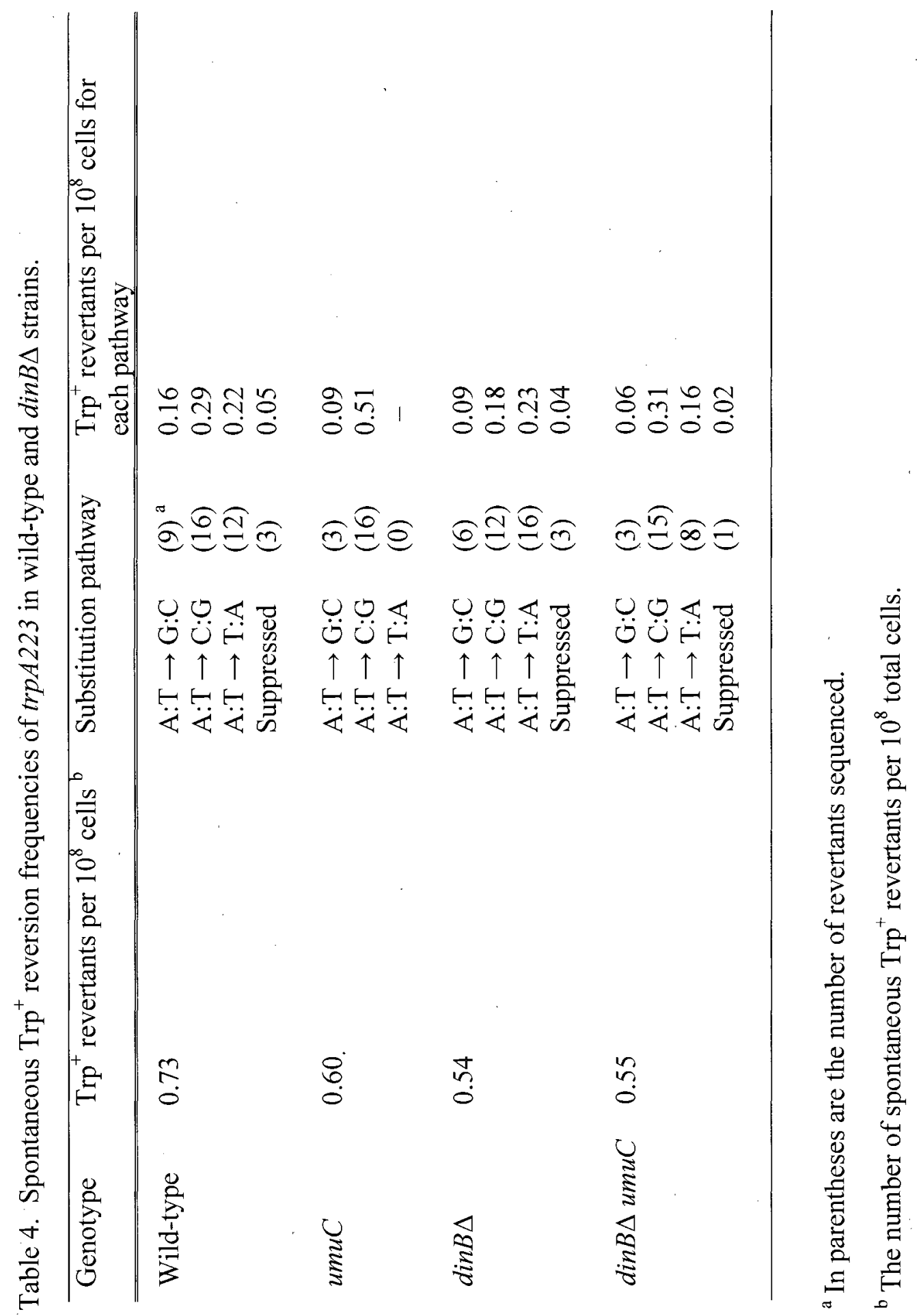




\section{DISCUSSION}

\subsection{The role of DinB in UV damage repair}

UV light can form DNA lesions, such as T-T pyrimidine $(6-4)$ pyrimidone photoproducts and cis-syn cyclobutane T-T dimer, which interfere with DNA replication and transcription. If the damage is left unrepaired, it can cause mutation, malfunction, and cell death. There are DNA repair mechanisms in cells for preventing these deleterious effects. In the presence of light, a specialized UV damage repair pathway in E. coli is photoreactivation. An enzyme, photolyase, binds specifically to the photoproduct and directly reverses the damage in an error-free manner by absorbing a photon of the appropriate wavelength (350-450 nm) and using the energy to break the dimer covalent bond. Nuclear excision repair (NER) is an error-free repair mechanism that can correct the pyrimidine dimer without the need of light. NER in E. coli removes the damage by generating nicks at a specific distance $5^{\prime}$ and $3^{\prime}$ from the damaged bases and excises the short single-stranded DNA. Pol I then fills the gaps in the $5^{\prime} \rightarrow 3^{\prime}$ direction, and DNA ligase seals the nick. When cells are overwhelmed by UV damage and lesions persist in the DNA, the SOS response will be triggered. There are more than 40 genes regulated by the $\operatorname{lex} A$ and $\operatorname{rec} A$ in the SOS regulatory network, including $\operatorname{din} B$ and $u m u C$.

Results from this study show that in the 20-hour growth curve experiment on UV survival, $\operatorname{din} B$ was found to be essential for full UV resistance. During log phase of growth, there was a significant reduction in the UV survival level of the $\operatorname{din} B \triangle$ strain 
compared to wild-type. As the growth enters stationary phase, the UV repair efficiency of the $\operatorname{din} B \Delta$ strain improves to the level slightly lower than that of the wild-type. In the stationary phase, perhaps some other proteins are recruited to the site of DNA lesions to assist in UV damage repair when DinB is absent.

The UV survival data here show that DinB's activity in UV survival is absolutely depended on $U m u D / C$. The two strains, $\operatorname{din} B \Delta$ and $\operatorname{din} B \triangle u m u C$, show the same level of UV survival (Fig. 2). This suggests that in the absence of umuD/C, DinB does not protect cells against UV damage. DinB and UmuD/C are likely to be working in close association on UV damage repair.

The effect of $\operatorname{din} B \triangle$ in UV repair found in this study is inconsistent with the results found in some other studies. Courcelle et al. (2005) and Wrzesiński et al. (2005) found no effect of $\operatorname{din} B$ in UV survival. The same $\operatorname{din} B$ strain with the $\operatorname{din} B \Delta$ polar mutation was presumably used in all three studies. One possible explanation for the differences is that the stage of the cell growth cycle at the time of UV exposure could be different between this study and the other two studies. The other two studies examined UV sensitivity at only one time point in the late log phase. It is worth noting that $\operatorname{din} B \Delta$ has been found to increase both UV and ionizing radiation sensitivity in another study (N. Sargentini, personal communication). It appears that DinB is essential in UV repair at $\log$ phase, and has a lesser effect in stationary phase.

The role of DinB in UV repair could be to allow UmuD/C to gain access to the replication fork to perform translesion synthesis where DNA synthesis occurs past the 
UV-induced lesions or simply delay the progression of the replication fork. A recent study showed that the presence of DinB does slow the replication fork (Indiani et al., 2009). The interactions between $\mathrm{DinB}$ and $\mathrm{UmuD}_{2}$ may be disrupted when $\mathrm{UmuD} / \mathrm{C}$ is missing (Godoy et al., 2007). Thus, DinB cannot improve the UV survival in the absence of $\mathrm{UmuD} / \mathrm{C}$. When an UV-induced lesion is encounted by the replicative polymerase, UmuD and UmuC delay the resumption of DNA replication to allow nucleotide excision repair additional time to repair the damage accurately before replication is resumed (Opperman et al., 1999). If the lesion could not be fixed in about $20 \mathrm{~min}$, the ssDNA:RecA nucleoprotein filament induces the autoproteolytic processing of $\mathrm{UmuD,}$ and UmuD' becomes the predominant form available to interact with UmuC which can lead to translesion synthesis past the lesion (Opperman et al., 1999; Burckhardt et al., 1988; Nohmi et al., 1988). Direct interactions amongst DinB, UmuD, $\mathrm{UmuD}_{2}^{\prime}$, and RecA, are found under physiological conditions (Godoy et al., 2007). It was found that DinB replaces the stalled Pol III holoenzyme on the $\beta$-clamp at the replication fork (Furukohri et al., 2008). By doing so, DinB may improve the accessibility for UmuD/C to perform translesion synthesis past lesions.

\subsection{The effect of polar $\operatorname{din} B \Delta$ and nonpolar $\operatorname{din} B 10$ on $\mathrm{UV}$ damage repair}

In this study, the effects on UV damage repair of two different $\operatorname{din} B$ alleles were compared. The nonpolar $\operatorname{din} B 10$ allele contains a missense mutation. A previous study had shown that a nonpolar $\operatorname{din} B 10$ mutation with a replacement of a highly conserved amino acid (R49F) does not have an effect on cell survival after UV damage (Mckenzie 
et al., 2001). In the polar $\operatorname{din} B \Delta$ strain, most of the $\operatorname{din} B$ gene and the first part of the downstream yaf $N$ gene are deleted. The data in Fig. 2 show that only the $\operatorname{din} B \Delta$ strain affects UV survival when compared to the wild-type. Its effect seems to depend upon the stage of the growth the cells are in at the time of plating. In contrast to the polar $\operatorname{din} B \Delta$ deletion, the nonpolar $\operatorname{din} B 10$ allele does not reduce the level of UV survival compared to the wild-type during log phase of growth. This suggests that DinB may not act as a polymerase but play another important role during UV repair. It appears that the DinB protein encoded by dinB10 is able to displace pol III and allow other repair machinery to remove the UV damage, but the DinB protein made by the $\operatorname{din} B \Delta$ allele cannot. As mentioned previously, the stalled Pol III holoenzyme was found to be replaced with DinB on the $\beta$-clamp at the replication fork (Furukohri et al., 2008). DinB gains access to the primer terminus and recruits another specialized polymerase to perform the translesion DNA synthesis, probably UmuClD (DNA pol V). DinB could also be playing a role in delaying the resumption of DNA replication to allow nucleotide excision repair time to repair the damage accurately before replication is resumed.

The downstream genes of $\operatorname{din} B$ could also be involved in UV-induced DNA repair during the exponential stage of growth. The downstream genes of $\operatorname{din} B$ are yaf $N$, yafO, and yafP. The functions of the yaf genes are not clear. The YafN protein, encoded by yaf $N$ gene, is homologous to the anti-toxin of the relBE operon of E. coli (Grønlund and Gerdes, 1999). The yafO gene is believed to be the toxin gene that produces YafO that pairs with YafN (Brown and Shaw, 2003). Toxicity was found associated with the overexpression of yafO. However, the antitoxicity of YafN against the YafO toxin has 
not been shown (Brown and Shaw, 2003). Mckenzie et al. (2003) suggest that yafN could be an anti-toxin gene that regulates the function of another yet to be discovered toxin gene. The yaf $N$ mutant (which would also be the case for the polar dinB $\Delta$ mutant) might experience killing due to lacking antitoxin in the presence of toxin during SOS induction (Mckenzie et al., 2003). This could be another possible explanation for the polar $\operatorname{din} B \Delta$ strain being more sensitive to UV irradiation compared to the nonpolar $\operatorname{din} B 10$ and the wild-type strains.

\subsection{The role of $\operatorname{din} B$ in $\mathrm{UV}$-induced mutagenesis and spontaneous mutagenesis}

The involvement of DinB in UV mutagenesis is not clear. One study shows that $\operatorname{din} B$ has a slight effect on UV mutagenesis (Wrzesiński et al., 2005). In contrast, this study suggests that $\operatorname{din} B$ does not contribute significantly to UV mutagenesis (Table 2), although a possible small effect cannot be eliminated.

An effect of $\operatorname{din} B$ in spontaneous mutagenesis was reported in previous studies. Some studies show that $\operatorname{din} B$ is involved in spontaneous mutagenesis, especially when it is overexpressed (Strauss et al., 2000; Lenne-Samuel et al., 2002; McKenzie et al., 2001; Kuban 2005; Jacob et al., 2007). DinB was shown to be involved in the mutagenesis of undamaged bacteriophage $\lambda$ DNA when grown on a UV-irradiated host (BrotcorneLannoye and Maenhaut-Michel, 1986). These studies showed an increase in spontaneous mutagenesis with overexpression of $\operatorname{din} B$. Other studies suggest that $\operatorname{din} B$ does not contribute to spontaneous mutagenesis when it is expressed at basal levels in dividing cells (Tago et al., 2005; Kuban et al., 2005). In contrast, Strauss et al. (2000) did find a 
small reduction in spontaneous mutagenesis in a $\operatorname{din} B$ strain. The data in Table 3 show that $\operatorname{din} B \triangle$ does not have a large effect on spontaneous mutagenesis in growing cells. Another study performed on the $\operatorname{trp} A 46$ strain showed a slight decrease in $\operatorname{din} B \Delta$ spontaneous mutagenesis compared to the wild-type strain (R. Fowler, unpublished data).

The base-pair substitution mutation of trpA223 strain is located in a GATC sequence. The adenine at the GATC site is methylated during DNA replication by a methylase encoded by the dam gene (Edmonds et al., 1992; Løbner-Olesen et al., 2005). $\mathrm{A}: \mathrm{T} \rightarrow \mathrm{G}: \mathrm{C}$ transitions typically occur more frequently than $\mathrm{A}: \mathrm{T} \rightarrow \mathrm{C}: \mathrm{G}$ transversions in the $\operatorname{trp} A$ gene (Bhamre et al., 2001). However, the data in Table 4 show that the $\mathrm{A}: \mathrm{T} \rightarrow$ $\mathrm{C}: \mathrm{G}$ transversion is occurring more frequently than the $\mathrm{A}: \mathrm{T} \rightarrow \mathrm{G}: \mathrm{C}$ transition among all strains. The A:T base pair is identical with both events. Since GATC methylation can influence cellular functions such as DNA mismatch repair, gene transcription, initiation of chromosome replication, and nucleoid structure (Løbner-Olesen et al., 2005), the results in this study showing a relatively lower frequency of transitions compared to transversions could be due to the methylation of adenine.

The $u m u C$ allele has been shown to decrease the spontaneous levels of some basepair substitutions (Bhamre et al., 2001). With the trpA223 allele, it appears to reduce $\mathrm{A}: \mathrm{T} \rightarrow \mathrm{T}: \mathrm{A}$ transverions. 


\section{LITERATURE CITED}

Bhamre, S., Gadea, B. B., Koyama, C. A., White, S. J., \& Fowler, R. G. (2001). An aerobic recA-, umuC-dependent pathway of spontaneous base-pair substitution mutagenesis in Escherichia coli. Mutat Res., 473(2), 229-47.

Blattner, F. R., Plunkett, G., Bloch, C. A., Perna, N. T., Burland, V., Riley, M., ColladoVides, J., Glasner, J. D., Rode, C. K., Mayhew, G. F., Gregor, J., Davis, N. W., Kirkpatrick, H. A., Goeden, M. A., Rose, D. J., Mau, B., \& Shao, Y. (1997). The complete genome sequence of Escherichia coli K-12. Science, 277(5331), 145374.

Bonner, C. A., Randall, S. K., Rayssiguier, C., Radman, M., Eritja, R., Kaplan, B. E., McEntee, K., \& Goodman, M. F. (1988). Purification and characterization of an inducible Escherichia coli DNA polymerase capable of insertion and bypass at abasic lesions in DNA. J Biol Chem., 263(35), 18946-52.

Boudsocq, F., Kokoska, R. J., Plosky, B. S., Vaisman, A., Ling, H., Kunkel, T. A., Yang, W., \& Woodgate, R. (2004). Investigating the role of the little finger domain of Y-family DNA polymerases in low fidelity synthesis and translesion replication. J Biol Chem., 279(31), 32932-40.

Brotcorne-Lannoye, A., \& Maenhaut-Michel, G. (1986). Role of RecA protein in untargeted UV mutagenesis of bacteriophage $\lambda$ : evidence for the requirement for the dinB gene. Proc Natl Acad Sci U S A., 83(11), 3904-8.

Brown, J. M., \& Shaw, K. J. (2003). A Novel Family of Escherichia coli toxinantitoxin gene pairs. $J$ Bacteriol., 185(22), 6600-08.

Burckhardt, S. E., Woodgate, R., Scheuermann, R. H., \& Echols, H. (1988). UmuD mutagenesis protein of Escherichia coli: overproduction, purification, and cleavage by RecA. Proc Natl Acad Sci U S A., 85(6), 1811-15.

Cai, H., Yu, H., McEntee, K., \& Goodman, M. F. (1995). Purification and properties of DNA polymerase II from Escherichia coli. Methods Enzymol., 262, 13-21.

Courcelle, C. T., Belle, J. J., \& Courcelle, J. (2005). Nucleotide excision repair or polymerase V-mediated lesion bypass can act to restore UV-arrested replication forks in Escherichia coli. J Bacteriol., 187(20). 6953-61.

Cox, E. C., Degnen, G. E., \& Scheppe, M. L. (1972). Mutator gene studies in Escherichia coli: the mutS gene. Genetics, 72(4), 551-67.

Craig, N. L., \& Roberts, J. W. (1980). E. coli recA protein-directed cleavage of phage $\lambda$ repressor requires polynucleotide. Nature, 283(5742), 26-30. 
Edmonds, P., Hall, B. M., Edwards, W. R., \& Hartline, K. M. (1992). Presence of methylated adenine in GATC sequences in chromosomal DNAs from Campylobacter species. J Bacteriol., 174(24), 8156-7.

Elledge, S. J., \& Walker, G. C. (1983). Proteins required for ultraviolet light and chemical mutagenesis. Identification of the products of the $u m u C$ locus of Escherichia coli. Mol Biol., 164(2), 175-92.

Frank, E. G., Gonzalez, M., Ennis, D. G., Levine, A. S., \& Woodgate, R. (1996). In vivo stability of the Umu mutagenesis proteins: a major role for RecA.J Bacteriol., 178(12), 3550-6.

Friedberg, E. C., Walker, G. C., Siede, W., Wood, R. D., Schultz, R. A., \& Ellenberger, T. (2006). DNA Repair and Mutagenesis. Washington, DC: ASM Press.

Furukohri, A., Goodman, M. F., \& Maki, H. (2008). A dynamic polymerase exchange with Escherichia coli DNA polymerase IV replacing DNA polymerase III on the sliding clamp. J Biol Chem., 283(17). 11260-9.

Godoy, V. G., Jarosz, D. F., Simon, S. M., Abyzov, A., Ilyin, V., \& Walker, G. C. (2007). UmuD and RecA Directly Modulate the Mutagenic Potential of the Y-family DNA Polymerase DinB. Mol Cell., 28(6), 1058-70.

Goodman, M. F. (2007). Error-prone repair DNA polymerases in prokaryotes and eukaryotes. Annu Rev Biochem., 71, 17-50.

Grønlund, H., \& Gerdes, K. (1999). Toxin-antitoxin systems homologous with relBE of Escherichia coli plasmid P307 are ubiquitous in prokaryotes. $J$ Mol Biol., 285(4), 1401-15.

Hall, B. G. (1998). Adaptive mutagenesis: a process that generates almost exclusively beneficial mutations. Genetica, 102-103(1-6), 109-25.

Indiani, C., Langston, L. D., Yurieva, O., Goodman, M. F., \& O'Donnell, M. (2009). Translesion DNA polymerases remodel the replisome and alter the speed of the replicative helicase. Proc Natl Acad Sci US A., doi:10.1073/pnas.0901403106

Jacob, K. D., \& Eckert, K. A. (2007). Escherichia coli DNA polymerase IV contributes to spontaneous mutagenesis at coding sequences but not microsatellite alleles. Mutat Res., 619(1-2), 93-103.

Jarosz, D. F., Godoy, V. G., Delaney, J. C., Essigmann, J. M., \& Walker, G. C. (2006). A single amino acid governs enhanced activity of DinB DNA polymerases on damaged templates. Nature, 439(7073), 225-8. 
Jarosz, D. F., Godoy, V. G., \& Walker, G. C. (2007). Proficient and accurate bypass of persistent DNA lesions by DinB DNA polymerases. Cell Cycle, 6(7), 817-22.

Johnson, R. E., Trincao, J., Aggarwal, A. K., Prakash, S., \& Prakash, L. (2003). Deoxynucleotide triphosphate binding mode conserved in Y family DNA polymerases. Mol Cell Biol., 23(8), 3008-12.

Kato, T., \& Shinoura, Y. (1977). Isolation and characterization of mutants of Escherichia coli deficient in induction of mutations by ultraviolet light. Mol Gen Genet., 156(2), 121-31.

Kenyon, C. J., \& Walker, G. C. (1980). DNA-damaging agents stimulate gene expression at specific loci in Escherichia coli. Proc Natl Acad Sci US A., 77(5), 2819-23.

Kim, S. R., Maenhaut-Michel, G., Yamada, M., Yamamoto, Y., Matsui, K., Sofuni, T., Nohmi, T., \& Ohmori, H. (1997). Multiple pathways for SOS-induced mutagenesis in Escherichia coli: an overexpression of $\operatorname{din} B /$ dinP results in strongly enhancing mutagenesis in the absence of any exogenous treatment to damage DNA. Proc Natl Acad Sci U S A., 94(25):13792-7.

Kim, S. R., Matsui K., Yamada M., Gruz P., \& Nohmi, T. (2001). Roles of chromosomal and episomal $\operatorname{din} B$ genes encoding DNA Pol IV in targeted and untargeted mutagenesis in Escherichia coli. Mol Genet Genomics., 266(2), 207-15.

Kuban, W., Banach-Orlowska, M., Bialoskorska, M., Lipowska, A., Schaaper, R. M., Jonczyk, P., \& Fijalkowska, I. J. (2005). Mutator phenotype resulting from DNA polymerase IV overproduction in Escherichia coli: preferential mutagenesis on the lagging strand. J Bacteriol., 187(19), 6862-6.

Kusumoto, R., Masutani, C., Shimmyo, S., Iwai, S., \& Hanaoka, F. (2004). DNA binding properties of human DNA polymerase $\eta$ : implications for fidelity and polymerase switching of translesion synthesis. Genes Cells, 9(12), 1139-50.

Lenne-Samuel, N., Wagner J., Etienne H., \& Fuchs R. P. (2002). The processivity factor $\beta$ controls DNA polymerase IV traffic during spontaneous mutagenesis and translesion synthesis in vivo. EMBO Rep., 3(1), 45-9.

Lennox, E. S. (1955). Transduction of linked genetic characterization of host by bacteriophage P1. Virology, 1(2), 190-206.

Ling, H., Boudsocq, F., Woodgate, R., \& Yang, W. (2001). Crystal structure of a Y-family DNA polymerase in action: a mechanism for error-prone and lesion-bypass replication. Cell, 107(1), 91-102.

Løbner-Olesen, A., Skovgaard, O., \& Marinus, M. G. (2005). Dam methylation: coordinating cellular processes. Curr Opin Microbiol., 8(2), 154-60. 
Maor-Shoshani, A., Reuven, N. B., Tomer, G., \& Livneh, Z. (2000). Highly mutagenic replication by DNA polymerase $\mathrm{V}(\mathrm{UmuC})$ provides a mechanistic basis for SOS untargeted mutagenesis. Proc Natl Acad Sci U SA., 97(2), 565-70.

McKenzie, G. J., Lee, P. L., Lombardo, M. J., Hastings, P. J., \& Rosenberg, S. M. (2001). SOS mutator DNA polymerase IV functions in adaptive mutation and not adaptive amplification. Mol Cell., 7(3), 571-79.

McKenzie, G. J., Magner, D. B., Lee, P. L., \& Rosenberg, S. M. (2003). The dinB operon and spontaneous mutation in Escherichia coli. J Bacteriol., 185(13), 3972-7.

Minko, I. G., Yamanaka, K., Kozekov, I. D., Kozekova, A., Indiani, C., O'Donnell, M. E., Jiang, Q., Goodman, M. F., Rizzo, C. J., \& Lloyd, R. S. (2008). Replication bypass of the acrolein-mediated deoxyguanine DNA-peptide cross-links by DNA polymerases of the DinB family. Chem Res Toxicol., 21(10), 1983-90.

Nohmi, T., Battista, J. R., Dodson, L. A., \& Walker, G. C. (1988). RecA-mediated cleavage activates UmuD for mutagenesis: mechanistic relationship between transcriptional derepression and posttranslational activation. Proc Natl Acad Sci USA., 85(6), 1816-20.

Ohashi, E., Bebenek, K., Matsuda, T., Feaver, W. J., Gerlach, V. L., Friedberg, E. C., Ohmori, H., \& Kunkel, T. A. (2000). Fidelity and processivity of DNA synthesis by DNA polymerase $\kappa$, the product of the human DINB1 gene. $J$ Biol Chem., 275(50), 39678-84.

Ohmori, H., Hatada, E., Qiao, Y., Tsuji, M., \& Fukuda, R. (1995). dinP, a new gene in Escherichia coli, whose product shows similarities to UmuC and its homologues. Mutat Res., 347(1):1-7.

Ohmori, H., Friedberg, E. C., Fuchs, R. P., Goodman, M. F., Hanaoka, F., Hinkle, D., Kunkel, T. A., Lawrence, C. W., Livneh, Z., \& Nohmi, T. (2001). The Y-family of DNA polymerases. Mol Cell., 8(1), 7-8.

Opperman, T., Murli, S., Smith, B. T., \& Walker, G. C. (1999). A model for a umuDCdependent prokaryotic DNA damage checkpoint Proc Natl Acad Sci US A., 96(16), 9218-23.

Perry, K. L., Elledge, S. J., Mitchell, B. B., Marsh, L., \& Walker, G. C. (1985). umuDC and $m u c A B$ operons whose products are required for UV light- and chemicalinduced mutagenesis: UmuD, MucA, and LexA proteins share homology. Proc Natl Acad Sci U S A., 82(13), 4331-5. 
Pham, P., Bertram, J. G., O'Donnell, M., Woodgate, R., \& Goodman, M. F. (2001). A model for SOS-lesion-targeted mutations in Escherichia coli. Nature, 409(6818), 366-70.

Qiu, Z., \& Goodman, M. F. (1997). The Escherichia coli polB locus is identical to dinA, the structural gene for DNA polymerase II. Characterization of Pol II purified from a polB mutant. $J$ Biol Chem., 272(13), 8611-7.

Rangarajan, S., Woodgate, R., \& Goodman, M. F. (1999). A phenotype for enigmatic DNA polymerase II: a pivotal role for pol II in replication restart in UV-irradiated Escherichia coli. Proc Natl Acad Sci U S A., 96(16), 9224-9.

Reuven, N. B., Arad, G., Maor-Shoshani, A., \& Livneh, Z. (1999). The mutagenesis protein UmuC is a DNA polymerase activated by UmuD', RecA, and SSB and is specialized for translesion replication. $J$ Biol Chem., 274(45), 31763-66.

Russell, P. (2003). Essential iGenetics. San Francisco: Benjamin Cummings.

Sargentini, N. J., \& K. C. Smith. (1987). Ionizing and ultraviolet radiation-induced reversion of sequenced frameshift mutations in Escherichia coli: a new role for umuDC suggested by delayed photoreactivation. Mutat Res., 179(1), 55-63.

Sargentini, N. J., \& K. C. Smith. (1989). Role of ruvAB genes in UV- and gammaradiation and chemical mutagenesis in Escherichia coli. Mutat Res., 215(1), $115-29$.

Sassanfar, M., \& Roberts, J. (1991). Constitutive and UV-mediated activation of RecA protein: combined effects of recA441 and recF143 mutations and of addition of nucleosides and adenine. $J$ Bacteriol., 173(18), 5869-75.

Shinagawa, H., Iwasaki, H., Kato, T., \& Nakata, A. (1988). RecA protein-dependent cleavage of UmuD protein and SOS mutagenesis. Proc Natl Acad Sci U S A., 85(6), 1806-10.

Sommer, S., Boudsocq, F., Devoret, R., \& Bailone, A. (1998). Specific RecA amino acid changes affect RecA-UmuD'C interaction. Mol Microbiol., 28(2):281-91.

Strauss, B. S., Roberts, R., Francis, L., \& Pouryazdanparast, P. (2000). Role of the $\operatorname{din} B$ gene product in spontaneous mutation in Escherichia coli with an impaired replicative polymerase. $J$ Bacteriol., 182(23), 6742-50.

Sutton, M. D., Opperman, T., \& Walker, G. C. (1999). The Escherichia coli SOS mutagenesis proteins $\mathrm{UmuD}$ and $\mathrm{UmuD}^{\prime}$ interact physically with the replicative DNA polymerase. Proc Natl Acad Sci U S A., 96(22), 12373-78. 
Tago, Y., Imai, M., Ihara, M., Atofuji, H., Nagata, Y., \& Yamamoto, K. (2005). Escherichia coli mutator $\triangle$ polA is defective in base mismatch correction: the nature of in vivo DNA replication errors. Mol Cell., 351(2). 299-308.

Tang, M., Shen, X., Frank, E. G., O'Donnell, M., Woodgate, R., \& Goodman, M. F. (1999). UmuD' ${ }_{2} \mathrm{C}$ is an error-prone DNA polymerase, Escherichia coli Pol V. Proc Natl Acad Sci US A., 96(16), 8919-24.

Tang, M., Pham, P., Shen, X., Taylor, J. S., O'Donnell, M., Woodgate, R., \& Goodman, M. F. (2000). Roles of E. coli DNA polymerases IV and V in lesion-targeted and untargeted SOS mutagenesis. Nature, 404(6781), 1014-18.

Tessman, I., \& Kennedy, M. A. (1994). DNA polymerase II of Escherichia coli in the bypass of abasic sites in vivo. Genetics, 136(2), 439-48.

Tompkins, J. D., Nelson, J. L., Hazel, J. C., Leugers, S. L., Stumpf, J. D., \& Foster, P. L. (2003). Error-prone polymerase, DNA polymerase IV, is responsible for transient hypermutation during adaptive mutation in Escherichia coli.J Bacteriol., 185(11), 3469-72.

Uchida, K., Furukohri, A., Shinozaki, Y., Mori, T., Ogawara, D., Kanaya, S., Nohmi, T., Maki, H., \& Akiyama, M. (2008). Overproduction of Escherichia coli DNA polymerase DinB (Pol IV) inhibits replication fork progression and is lethal. Mol Microbiol., 70(3), 608-22.

Vogel, H. J., \& Bonner, D. M. (1956). Acetylornithinase of Escherichia coli: partial purification and some properties. J Biol Chem., 218(1), 97-106.

Wagner, J., Gruz, P., Kim, S. R., Yamada, M., Matsui, K., Fuchs, R. P., \& Nohmi, T. (1999). The $\operatorname{din} B$ gene encodes a novel E. coli DNA polymerase, DNA Pol IV, involved in mutagenesis. Mol Cell., 4(2), 281-286.

Wagner, J., Fujii, S., Gruz, P., Nohmi, T., \& Fuchs, R. P. (2000). The beta clamp targets DNA polymerase IV to DNA and strongly increases its processivity. EMBO Rep., $1(6), 484-88$.

Woodgate R. (1992). Construction of a umuDC operon substitution mutation in Escherichia coli. Mutat Res., 281(3), 221-5.

Woodgate R. (1999). A plethora of lesion-replicating DNA polymerases. Genes Dev., 13(17), 2191-5.

Wrzesiński, M., Nowosielska, A., Nieminuszczy, J., \& Grzesiuk, E. (2005). Effect of SOS-induced Pol II, Pol IV, and Pol V DNA polymerases on UVinduced mutagenesis and MFD repair in Escherichia coli cells. Acta Biochim Pol., $52(1), 139-47$. 